\title{
Partitioning of Solute Elements and Microstructural Changes during Heat- treatment of Cold-rolled High Strength Steel with Composite Microstructure
}

\author{
Tatsuya NaKagaito ${ }^{1)^{*}}$, Takako Yamashita ${ }^{1)}$, Yoshimasa FunAKaWA $^{2)}$ and Masanori Kajihara ${ }^{3)}$ \\ 1) Steel Research Laboratory, JFE Steel Corporation \\ 2) Sales Division, JFE Techno-Research Corporation \\ 3) Department of Materials Science and Engineering, Tokyo Institution of Technology
}

Abstract: The partitioning of solute elements during intercritical annealing and the effects of partitioning on ferrite transformation during slow cooling after intercritical annealing in a $0.17 \% \mathrm{C}-1.5 \% \mathrm{Si}-1.7 \% \mathrm{Mn}$ (mass $\%$ ) steel were investigated by a new FE-EPMA (field emission electron probe microanalysis) technique. This new technique enables highly accurate measurement of the $\mathrm{C}$ distribution. During the intercritical annealing, $\mathrm{C}$ and $\mathrm{Mn}$ concentrated into austenite, while Si concentrated into ferrite. The distribution of $\mathrm{Mn}$ in austenite was inhomogeneous, and austenite with small Mn content was transformed into ferrite during slow cooling. This ferrite transformation proceeded in the NPLE (negligible partitioning local equilibrium) mode. Two kinds of ferrite were produced due to slow cooling, one being intercritically-annealed ferrite, and the other transformed ferrite. The transformed ferrite had larger Mn content than the intercritically-annealed ferrite. Furthermore, the transformed ferrite was classified into the ferrite grown epitaxially from the intercritically-annealed ferrite and that nucleated in the austenite with relatively small Mn content. Prior microstructure and distribution of solute elements before cooling are determined by the intercritical annealing conditions, and then control the ferrite transformation. Precise control of the ferrite transformation is effective for stable production of cold-rolled high strength steel with composite microstructure.

Keywords: phase transformation; reverse transformation; ferrite transformation; dual phase; TRIP; intercritical annealing; partitioning; local equilibrium; paraequilibrium; phase diagram; thermodynamics.
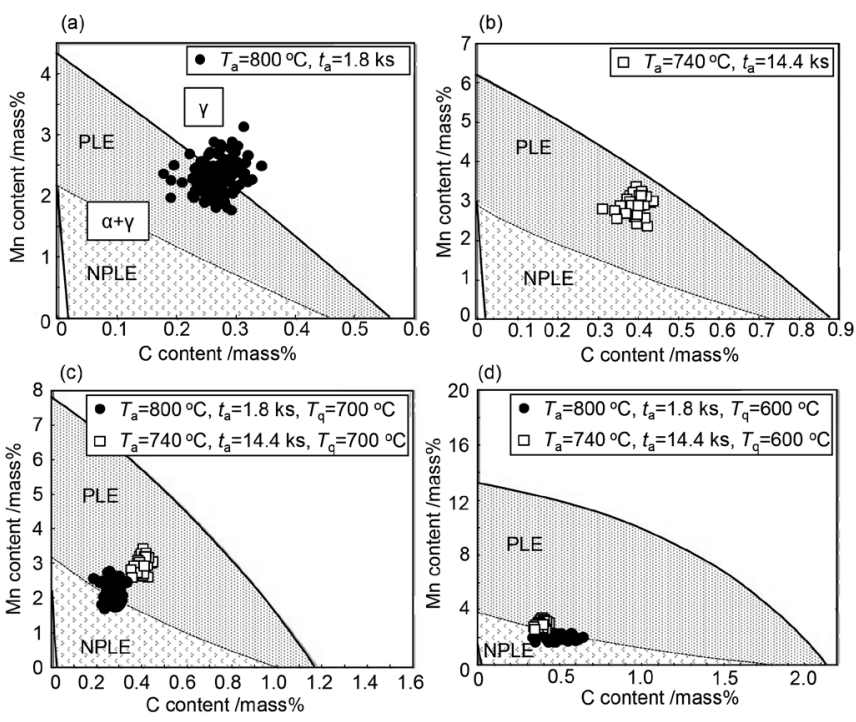

Received on Apr. 11, 2021; Accepted on Sep. 1, 2021; originally published in ISIJ Int., Vol.60 (2020), No.8, pp.1784-1795

* Corresponding author. E-mail: t-nakagaito@jfe-steel.co.jp, Address: JFE Steel Corporation, 1 Kokan-cho Fukuyama Hiroshima $721-8510$

(c) (i) $\odot 2022$ The Iron and Steel Institute of Japan. This is an open access article under the terms of the Creative Commons Attribution-NonCommercialNoDerivatives license (https://creativecommons.org/licenses/by-nc-nd/4.0/). 


\title{
複合組織冷延高強度鋼板の熱処理時の 溶質元素の分配と組織変化
}

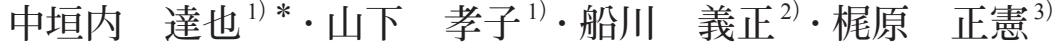 \\ Partitioning of Solute Elements and Microstructural Changes during Heat-treatment of Cold-rolled High Strength Steel \\ with Composite Microstructure \\ Tatsuya Nakagaito, Takako Yamashita, Yoshimasa Funakawa and Masanori Kajihara
}

\section{1. 緒言}

自動車の衝突安全性向上と $\mathrm{CO}_{2}$ 排出量削減の両立を目 的にDP (dual phase) 鋼板や低合金TRIP (transformation induced plasticity）鋼板のような冷延高強度鋼板の適用が進 められてきている。自動車メ一カーからの自動車用鋼板の 高強度化と成形性向上の要求と併せて, 鉄鋼メ一カーにお いてはこれらの鋼板の安定製造の観点での材質ばらつき の低減が重要となる。一般に，複合組織冷延高強度鋼板は フェライトとオーステナイトの二相域焼鈍後の制御冷却に より製造され，二相域焼鈍時には逆変態によるオーステナ イトの生成およびフェライトとオーステナイトへの溶質元 素の分配が生じる。高強度鋼板の製造において，二相域焼 鈍およびその後の制御冷却における相変態は非平衡な状態 で進行することから，その組織制御は複雑なものとなる。 したがって，鋼組織や機械的特性を精緻に制御するために は，二相域焼鈍後の相変態に及ぼす二相域焼鈍時の逆変態 挙動や溶質元素の分配の影響を理解することが非常に重要 となる ${ }^{1-5)}$ 。

Speich $~^{1)}$ は, 初期組織がフェライトとパーライトから なる C-Mn鋼の二相域焼鈍時のオーステナイトの生成挙動 を調査し, オーステナイトの形成は以下の 3 ステップで生 じることを報告している。（1）フェライトとパーライトと の界面の扎けるオーステナイトの核生成执よびオーステナ イトのパーライト側への急速な成長，(2) パーライトが消 滅した後のフェライト側へのさらなるオーステナイトの成 長，および (3) オーステナイト中の Mnの拡散に律速され るオーステナイトとフェライトへの $\mathrm{Mn}$ の分配による平衡 状態への到達。一方，Toji $5^{2)}$ は，二相域焼鈍時にオーステ ナイト中に Mnが濃化することでオーステナイトが化学的
に安定になり，二相域焼鈍後の空冷時のオーステナイトか らのフェライトの生成が抑制されることを報告している。 しかし, 従来の検討ではフェライトとオーステナイト中の $\mathrm{C}$ 濃度を広範囲の視野において実験的に測定することが難 しく，二相域焼鈍工程における相変態に及ぼすCや置換型 固溶元素の分配の影響の定量的な評価が困難であった。

本研究では, 上記の課題に対して, 新たに開発された高 精度 FE-EPMA (field emission electron probe microanalysis) 技 術 ${ }^{6,7)}$ を用いて検討を行った。この技術により, Mnや Siの ような置換型溶質元素だけでなく, Cの二次元分布も高精 度に可視化することが可能となる。この高精度 FE-EPMA 技術を用いた調査をもとに，二相域焼鈍後のフェライト変 態に及ぼす二相域焼鈍時の溶質元素の分配の影響について 数值計算も含めた定量的評価を行った。

\section{2. 実験方法}

供試鋼として Table 1 に示す組成の鋼を用いた。なお，表 中にはThermo-Calc ${ }^{\circledR}$ を用いてオルソ平衡で計算した $A_{\mathrm{el}}$ 点 および $A_{\mathrm{e} 3}$ 点も合わせて示す。 $A_{\mathrm{e} 1}$ 点はセメンタイトが完全 に固溶する温度，すなわちフェライトおよびオーステナイ トの二相領域と，フェライト，オーステナイト扎よ゙゙セメ ンタイトの三相領域の境界温度とした。供試鋼は $50 \mathrm{~kg}$ 真

Table 1. Chemical composition of steel used in experiment and calculated $A_{\mathrm{el}}$ and $A_{\mathrm{e} 3}$ temperatures.

\begin{tabular}{|c|c|c|c|c|c|c|c|}
\hline \multicolumn{6}{|c|}{ Chemical composition (mass\%) } & \multirow{2}{*}{$A_{\mathrm{e} 1}$} & \multirow{2}{*}{$A_{\mathrm{e} 3}$} \\
\hline $\mathrm{C}$ & $\mathrm{Si}$ & $\mathrm{Mn}$ & $\mathrm{P}$ & $\mathrm{S}$ & $\mathrm{Al}$ & & \\
\hline 0.17 & 1.5 & 1.7 & 0.010 & 0.001 & 0.03 & $\begin{array}{c}708^{\circ} \mathrm{C} \\
(981 \mathrm{~K})\end{array}$ & $\begin{array}{c}857^{\circ} \mathrm{C} \\
(1130 \mathrm{~K})\end{array}$ \\
\hline
\end{tabular}

原著論文 : ISIJ Int., Vol.60 (2020), No.8, pp.1784-1795

2021年4月11日受付 2021 年9月1日受理 (Received on Apr. 11, 2021; Accepted on Sep. 1, 2021; originally published in ISIJ Int., Vol.60 (2020), No.8, pp.1784-1795)

1）JFEスチール (株) スチール研究所 (Steel Research Laboratory, JFE Steel Corporation)

2) JFE テクノリサーチ (株) 営業本部 (Sales Division, JFE Techno-Research Corporation)

3）東京工業大学物質理工学院 (Department of Materials Science and Engineering, Tokyo Institution of Technology)

* Corresponding author. E-mail: t-nakagaito@jfe-steel.co.jp, Address: JFE Steel Corporation, 1 Kokan-cho Fukuyama Hiroshima $721-8510$ 
空溶解炉で溶製し, 粗圧延にて厚さ $27 \mathrm{~mm}$ のスラブとした 後, 加熱温度 $1250^{\circ} \mathrm{C}$ ，仕上げ圧延温度 $900^{\circ} \mathrm{C}$ で熱間圧延を 施し， $600^{\circ} \mathrm{C}$ で $1 \mathrm{~h}$ 保持する巻取り相当の熱処理を行い，板 厚 $4.0 \mathrm{~mm}$ の熱延板を作製した。得られた熱延板の表裏面 を板厚 $3.2 \mathrm{~mm}$ まで研削した後，板厚 $1.2 \mathrm{~mm}$ まで冷間圧延 を行い，次いで塩浴炉を用いて Fig.1に示すパターンA A お

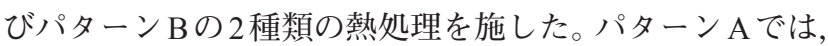
焼鈍温度 $\left(T_{\mathrm{a}}\right)$ が $800^{\circ} \mathrm{C}$ および $740^{\circ} \mathrm{C}$ の各条件において, 加 熱途中の各温度 $\left(T_{\mathrm{q}}\right)$ から，または， $T_{\mathrm{a}}$ で各時間 $\left(t_{\mathrm{a}}\right)$ 保持し た後，水焼入れを行い，二相域焼鈍時の逆変態挙動およひ 溶質元素の分配について調査を行った。一方，パターン B では，各条件での二相域焼鈍後に $10^{\circ} \mathrm{C} / \mathrm{s}$ の冷却速度で緩冷 却を行い, 冷却時の各温度 $\left(T_{\mathrm{q}}\right)$ から水焼入れを行うことで, 冷却時のフェライト変態挙動に及ぼす二相域焼鈍時の溶質 元素の分配の影響について調査を行った。

熱処理により得られた試料に対して，断面組織観察およ び高精度FE-EPMA 分析 ${ }^{6,7)}$ を行った。断面組織観察は，板 厚方向に平行な板厚断面 (上下が板厚方向) を研磨して, ナイタール $(1 \%$ 硝酸十エタノール) で腐食した試料を用 いて，光学顕微鏡および走査電子顕微鏡 (SEM: Scanning Electron Microscope) により行った。SEM像を用いてポイ ントカウンティング法により各相の体積率を定量化した。 さらに, 高精度FE-EPMA分析により, C, Mnおよび $\mathrm{Si}$ お 分布の定量面分析を行った。まず，表面のカーボンコンタ ミネーションを防ぎながら Cの測定を行った後, 同一視野 について Mn およびSiの測定を行った。Cの測定において 加速電圧は $7 \mathrm{kV}$, 照射電流は $5 \mathrm{nA} と し$, 続く $\mathrm{Mn}$ および $\mathrm{Si}$ の測定は $\mathrm{S} / \mathrm{N}$ 比の観点から加速電圧を $9 \mathrm{kV}$, 照射電流を 10 $\mathrm{nA}$ に変更して行った。C濃度の定量化には純鉄および $\mathrm{C}$ 濃 度が 0.089 から 0.680 mass\%の鋼を標準試料として用いた。 $\mathrm{Mn}$ 抢よび $\mathrm{Si}$ の濃度はZAF ${ }^{{ }^{8}}{ }^{8)}$ により定量化した。

\section{(Pattern A)}

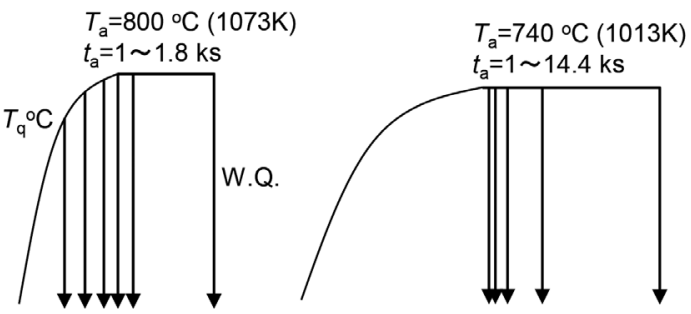

(Pattern B)

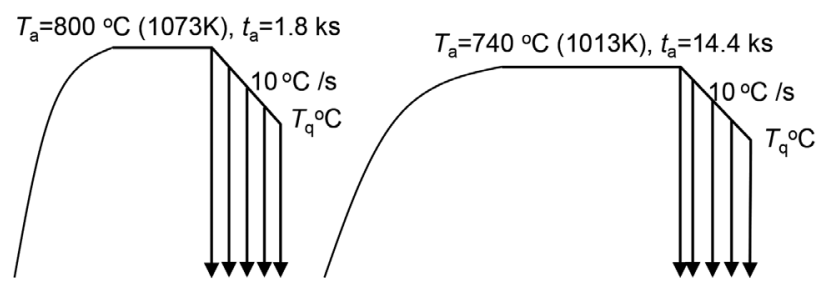

Fig. 1. Schematic diagrams of heat treatment patterns.

\section{3. 実験結果}

\section{$3 \cdot 1$ 二相域焼鈍時の逆変態および溶質元素の分配}

Fig.2 に，供試鋼の熱延板の光学顕微鏡組織を示す。熱延 板の組織はフェライトとパーライトからなり，フェライト の平均粒径は約 $10 \mu \mathrm{m}$ であった。偏析やバンド状組織の形 成は認められず, 均一な組織となっており, 熱延板での Mn や Siの顕著な偏析は生じていないと考えられる。焼鈍時の オーステナイトの生成挙動に対して，このような初期組織 も影響を及ぼすことが報告されているが ${ }^{9-12)}$ ，本研究では 冷延鋼板の母板として一般的なフェライト十パーライト組 織の熱延板を用いた。

Fig.3に，パターンAの熱処理において，焼鈍温度 $T_{\mathrm{a}}=$ $800^{\circ} \mathrm{C}$ のきの加熱途中の各温度 $T_{\mathrm{q}}$ から水焼入れを行った 試料，および $800^{\circ} \mathrm{C}$ で各時間 $t_{\mathrm{a}}$ 保持した後，水焼入れを行っ た試料のSEM像を示す。Fig.3（a)，(b) 扎よび (c) はそれ ぞれ $T_{\mathrm{q}}=650^{\circ} \mathrm{C}, 740^{\circ} \mathrm{C}$ および $780^{\circ} \mathrm{C}$ の SEM像で, Fig.3 (d), (e) および (f) はそれぞれ $t_{\mathrm{a}}=1 \mathrm{~s}, 90 \mathrm{~s}$ および $1.8 \mathrm{ks}$ の SEM 像である。Fig.3 (a) および (b) では母相であるフェライト に球状のセメンタイトが分散した組織で，Fig.3 (a) では フェライト粒は伸展した形状であるのに対して, Fig.3 (b) では等軸な形状となっている。等軸な形状のフェライトは 再結晶フェライトであり，フェライトの再結晶は $650^{\circ} \mathrm{C}$ か ら $740^{\circ} \mathrm{C}$ の温度域で生じていることが分かる。Fig.3 (c) で はセメンタイトがほとんど消失し，再結晶フェライトの粒 界に沿ってマルテンサイトが認められる。このような水焼 入れ後のマルテンサイトは熱処理時のオーステナイトに相 当する。本研究では，水焼入れした試料のSEM像で観察さ れたマルテンサイトの体積率および分散状態を，熱処理時 のオーステナイトのものと同等として検討を行った。Fig.3 （b）および (c) より，フェライトからオーステナイトへの 逆変態は, $740^{\circ} \mathrm{C}$ か $780^{\circ} \mathrm{C}$ の温度域で開始することが分か

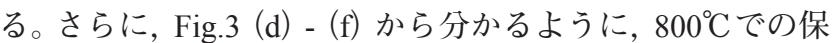
持時間の増加に伴いオーステナイトの体積率が増加する。

Fig.4に，パターンAの熱処理において，焼鈍温度 $T_{\mathrm{a}}=$

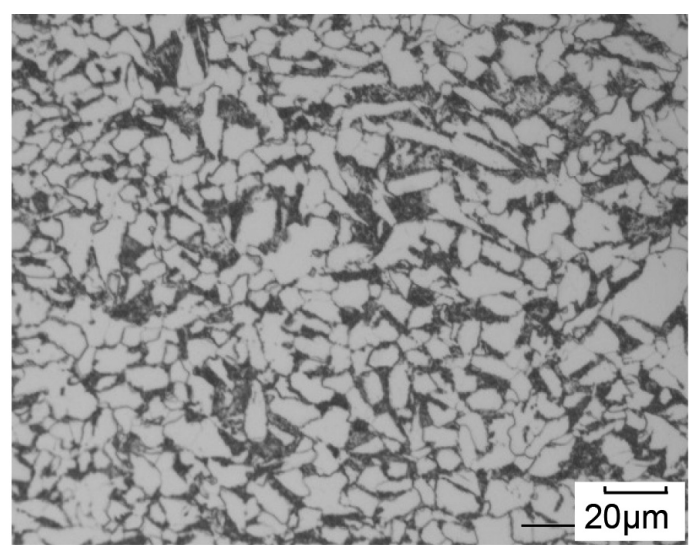

Fig. 2. Optical micrograph of hot-rolled sheet. 
$740{ }^{\circ} \mathrm{C}$ で各時間 $t_{\mathrm{a}}$ 保持した後，水焼入れを行った試料の SEM像を示す。Fig.4 (a) - (f) はそれぞれ $t_{\mathrm{a}}=1 \mathrm{~s}, 90 \mathrm{~s}$, 300 s, 900 s, 3.6 ks および 14.4 ksの SEM像である。Fig.4 (a) では, 再結晶フェライトと球状セメンタイトからなる組織 となっている。Fig.4 (b) ではフェライト粒界にオーステナ イトが認められ, Fig.4（e)においてセメンタイトが完全に 消失する。焼鈍時間の増加に伴いセメンタイトが減少し, オーステナイトの体積率が増加する。

Fig. 5 に, $T_{\mathrm{a}}=800^{\circ} \mathrm{C}, t_{\mathrm{a}}=1.8 \mathrm{ks} の$ 条件で熱処理した後, 水焼入れを行った試料について SEM観察を行った後, 同じ 視野について高精度FE-EPMA 分析を行った結果を示す。 Fig.5 (a) はSEM像で, Fig.5 (b)，(c) および (d) はそれぞ れC，Mn打よび $\mathrm{Si}$ 濃度の二次元マッピングである。Cおよ
び $\mathrm{Mn}$ 濃度が高い領域はオーステナイトに相当し, $\mathrm{Si}$ 濃度 が高い領域がフェライトに相当する。これは，二相域焼鈍 により，CおよびMnがオーステナイトに濃化し，Siがフェ ライトに濃化することによる。オーステナイト中のC 濃度 とフェライト中の $\mathrm{Si}$ 濃度の分布は小さいのに対して, オー ステナイト中の $\mathrm{Mn}$ 濃度は結晶粒の中央付近に対して粒界 付近で高くなる傾向があり，粒内で 1.4 mass\% 程度の大き な分布が認められる。これは，オーステナイト中の Mnの 拡散が，オーステナイト中のC 扎よびフェライト中の $\mathrm{Si}$ の 拡散に対して遅いことに起因すると考えられる。

Fig.6に, $T_{\mathrm{a}}=740^{\circ} \mathrm{C}, t_{\mathrm{a}}=14.4 \mathrm{ks}$ の条件で熱処理した後, 水焼入れして得られた試料について, Fig.5 と同様にSEM 観察および高精度FE-EPMA分析を行った結果を示す。
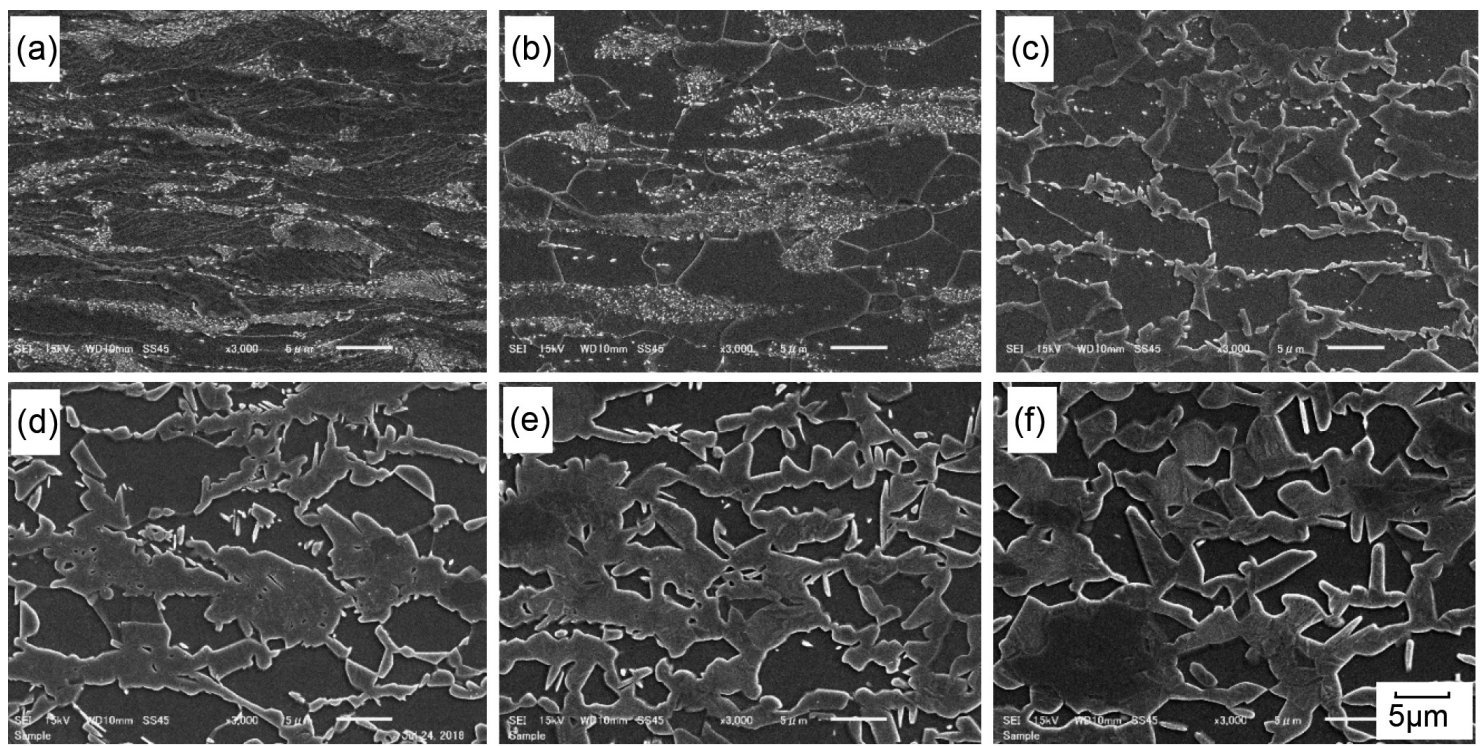

Fig. 3. SEM images of specimens for Pattern A at $T_{\mathrm{a}}=800^{\circ} \mathrm{C}(1073 \mathrm{~K})$ with (a) $T_{\mathrm{q}}=650^{\circ} \mathrm{C}$, (b) $T_{\mathrm{q}}=740^{\circ} \mathrm{C}$ and (c) $T_{\mathrm{q}}=780^{\circ} \mathrm{C}$ or with (d) $t_{\mathrm{a}}=1 \mathrm{~s}$, (e) $t_{\mathrm{a}}=90 \mathrm{~s}$ and (f) $t_{\mathrm{a}}=1.8 \mathrm{ks}$.
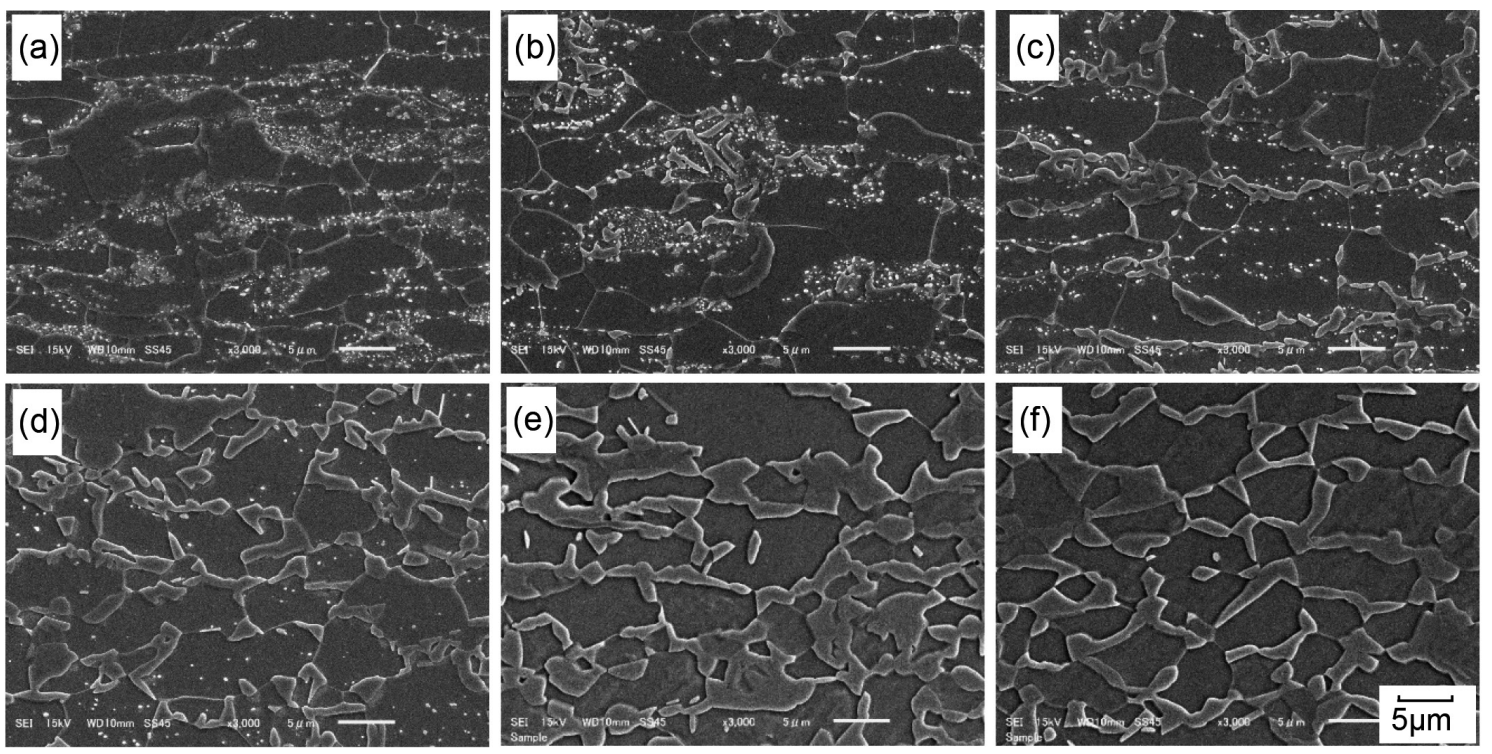

Fig. 4. SEM images of specimens for Pattern A at $T_{\mathrm{a}}=740^{\circ} \mathrm{C}(1013 \mathrm{~K})$ for (a) $t_{\mathrm{a}}=1 \mathrm{~s}$, (b) $t_{\mathrm{a}}=90 \mathrm{~s}$, (c) $t_{\mathrm{a}}=300 \mathrm{~s}$, (d) $t_{\mathrm{a}}=900 \mathrm{~s}$, (e) $t_{\mathrm{a}}=$ $3.6 \mathrm{ks}$ and (f) $t_{\mathrm{a}}=14.4 \mathrm{ks}$. 
Fig.5 と同様に，CおよびSi はそれぞれオーステナイトおよ びフェライト中に均一に濃化し，オーステナイトへの Mn 濃化は不均一に生じている。オーステナイト粒内の Mn 濃 度の分布は約 $1.0 \mathrm{mass} \%$ と, $T_{\mathrm{a}}=800^{\circ} \mathrm{C}$ に対して小さい。

Fig.7に, 焼鈍時間の増加に伴うオーステナイト中の各元 素の平均濃度の変化を示す。各元素の分布から求めた標準 偏差をエラーバーで示している。各元素の濃度を複数の結
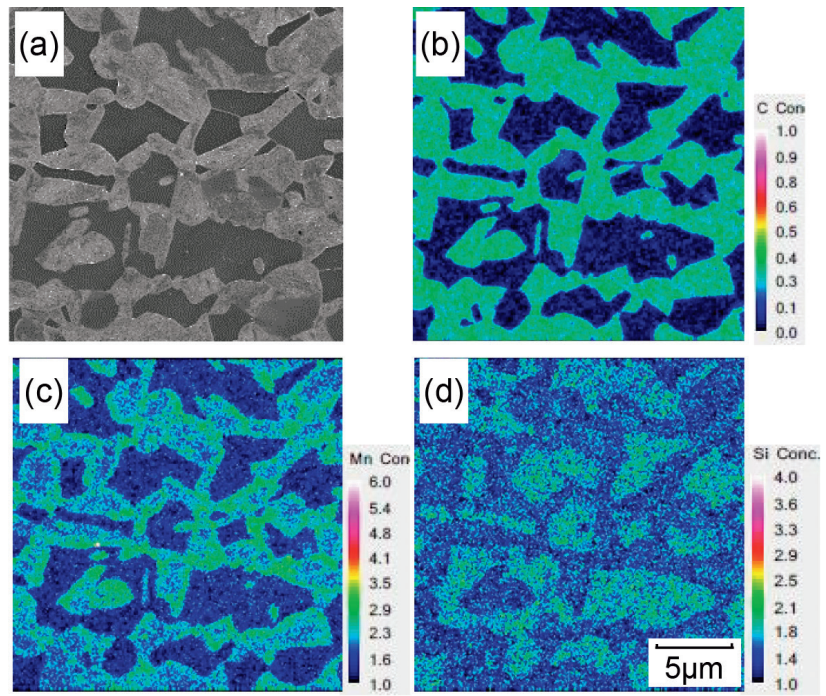

Fig. 5. (a) SEM image and corresponding EPMA elemental mappings of (b) $\mathrm{C}$, (c) $\mathrm{Mn}$ and (d) $\mathrm{Si}$ of specimen for Pattern A with $T_{\mathrm{a}}=800^{\circ} \mathrm{C}(1073 \mathrm{~K})$ and $t_{\mathrm{a}}=1.8 \mathrm{ks}$.
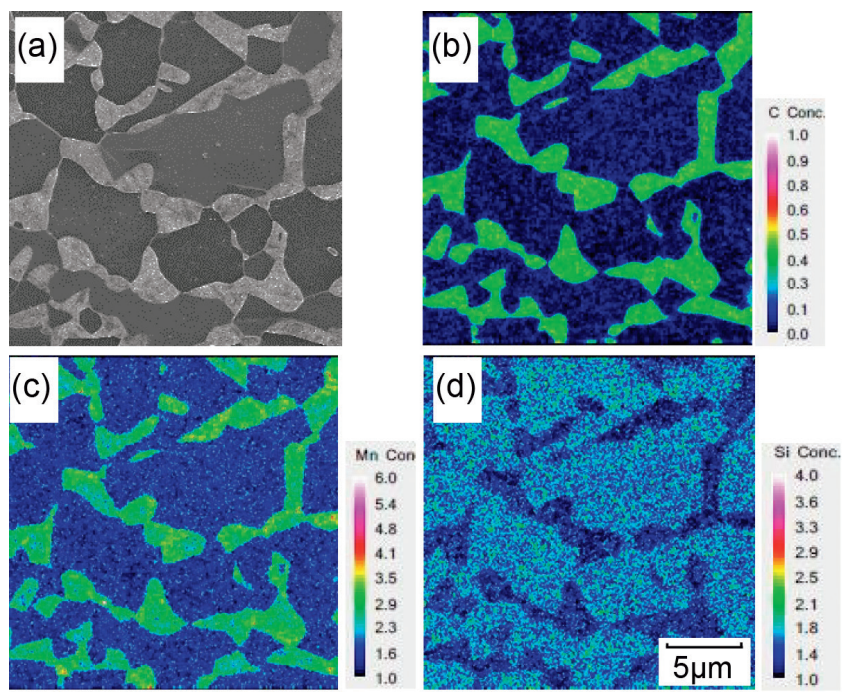

Fig. 6. (a) SEM image and corresponding EPMA elemental mappings of (b) $\mathrm{C}$, (c) $\mathrm{Mn}$ and (d) $\mathrm{Si}$ of specimen for Pattern A with $T_{\mathrm{a}}=740^{\circ} \mathrm{C}(1013 \mathrm{~K})$ and $t_{\mathrm{a}}=14.4 \mathrm{ks}$.
晶粒についてその粒内を $0.09 \mu \mathrm{m}$ の間隔で測定し, 平均濃 度および標準偏差を求めた。合わせて, Thermo-Calcにより 計算で求めた平衡状態でのオーステナイト中の Mn 扎よび $\mathrm{Si}$ 濃度も破線で図中に示す。焼鈍時間の増加に伴い $\mathrm{Mn}$ 濃 度が増加し, C および $\mathrm{Si}$ 濃度は減少する。Mnおよび $\mathrm{Si}$ 濃 度は共に焼鈍時間の増加により平衡濃度に近づき, 長時間 の焼鈍により到達する $\mathrm{Mn}$ 濃度は $T_{\mathrm{a}}=800^{\circ} \mathrm{C}$ に対して $T_{\mathrm{a}}=$

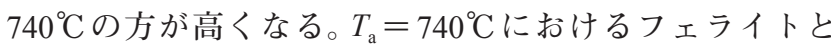
オーステナイトとの Mnの分配比は約 1.9 であり, Siよりも 顕著な分配が生じる。

\section{$3 \cdot 2$ 二相域焼鈍後のフェライト変態}

二相域焼鈍後の緩冷却時のフェライト変態挙動に及ほ す溶質元素の分配の影響について, パターンBの熱処理 条件で調査を行った。ここで，溶質元素の分配の状態を大 きく変化させることを目的に，二相域焼鈍は $T_{\mathrm{a}}=800^{\circ} \mathrm{C}$, $t_{\mathrm{a}}=1.8 \mathrm{ks}$ および $T_{\mathrm{a}}=740^{\circ} \mathrm{C}, t_{\mathrm{a}}=14.4 \mathrm{ks}$ 条件で行った。 Table 2 に各条件で焼鈍したときのフェライトおよびオー ステナイトの体積率，およびオーステナイト中のC，Mn お

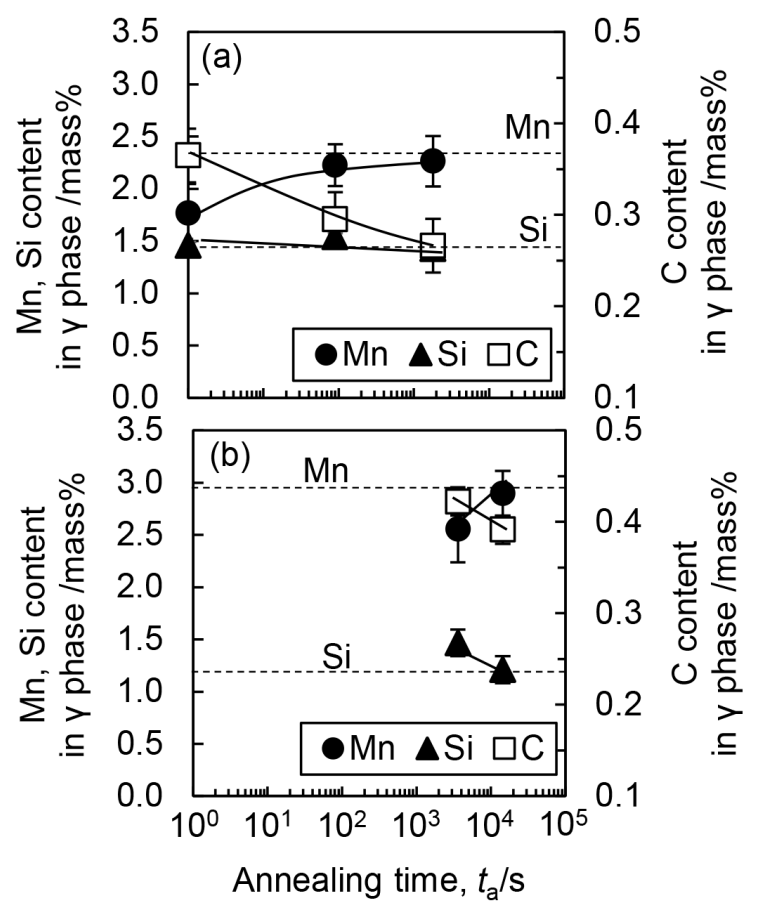

Fig. 7. Dependence of chemical composition for $\gamma$ phase on annealing time at (a) $T_{\mathrm{a}}=800^{\circ} \mathrm{C}(1073 \mathrm{~K})$ and (b) $T_{\mathrm{a}}=$ $740^{\circ} \mathrm{C}(1013 \mathrm{~K})$. Mean $\mathrm{C}, \mathrm{Mn}$ and $\mathrm{Si}$ contents are shown as open squares, solid circles and triangles, respectively, with error bars.

Table 2. Volume fractions, $f_{a}$ and $f_{\gamma}$, of ferrite and austenite, respectively, and mean contents of solute elements in austenite under various annealing conditions.

\begin{tabular}{c|c|c|c|c|c|c}
\hline \multicolumn{2}{c|}{ Annealing conditions } & \multicolumn{2}{c|}{ Volume fractions } & \multicolumn{3}{c}{ Mean contents in $\gamma$ phase } \\
\hline $\begin{array}{c}\text { Temperature, } \\
T_{\mathrm{a}} /{ }^{\circ} \mathrm{C}\end{array}$ & $\begin{array}{c}\text { Time, } \\
t_{\mathrm{a}} / \mathrm{ks}\end{array}$ & $\begin{array}{c}\alpha \text { phase, } \\
f_{\alpha}\end{array}$ & $\begin{array}{c}\gamma \text { phase, } \\
f_{\gamma}\end{array}$ & $\begin{array}{c}\mathrm{C} \\
/ \mathrm{mass}_{0}\end{array}$ & $\begin{array}{c}\mathrm{Mn} \\
/ \mathrm{mass} \%\end{array}$ & $\begin{array}{c}\mathrm{Si} \\
/ \mathrm{mass} \%\end{array}$ \\
\hline 800 & 1.8 & 0.34 & 0.66 & 0.27 & 2.1 & 1.3 \\
\hline 740 & 14.4 & 0.73 & 0.27 & 0.42 & 2.9 & 1.2 \\
\hline
\end{tabular}


よび $\mathrm{Si}$ の平均濃度を整理して示す。

Fig. 8 に, $T_{\mathrm{a}}=800^{\circ} \mathrm{C}, t_{\mathrm{a}}=1.8 \mathrm{ks}, T_{\mathrm{q}}=800-400^{\circ} \mathrm{C}$ の条件で 熱処理した試料の SEM像を示す。ここで, $T_{\mathrm{q}}=800^{\circ} \mathrm{C}$ は, 緩冷却を行わずに二相域焼鈍後にそのまま水焼入れを行っ たものである。全てのSEM像においてフェライトとマル テンサイトの二相組織となっており，フェライトの体積率 は水焼入れ温度の低下に伴い増加する。これは, 緩冷却時 にオーステナイトからフェライト変態が生じていることを 示している。 $T_{\mathrm{a}}=740^{\circ} \mathrm{C}, t_{\mathrm{a}}=14.4 \mathrm{ks}$ の焼鈍条件についても 同様に, $T_{\mathrm{q}}=740-400^{\circ} \mathrm{C}$ で熱処理を行った試料の SEM像を Fig.9 に示す。Fig.8 と同様に全ての条件でフェライトとマ ルテンサイトの二相組織であるが, 水焼入れ温度による組 織の変化はほとんど認められない。Fig.10に各焼鈍条件に おける水焼入れ温度とフェライト体積率との関係を示す。 $T_{\mathrm{a}}=800^{\circ} \mathrm{C}, t_{\mathrm{a}}=1.8 \mathrm{ks}$ の焼鈍条件において, フェライト体
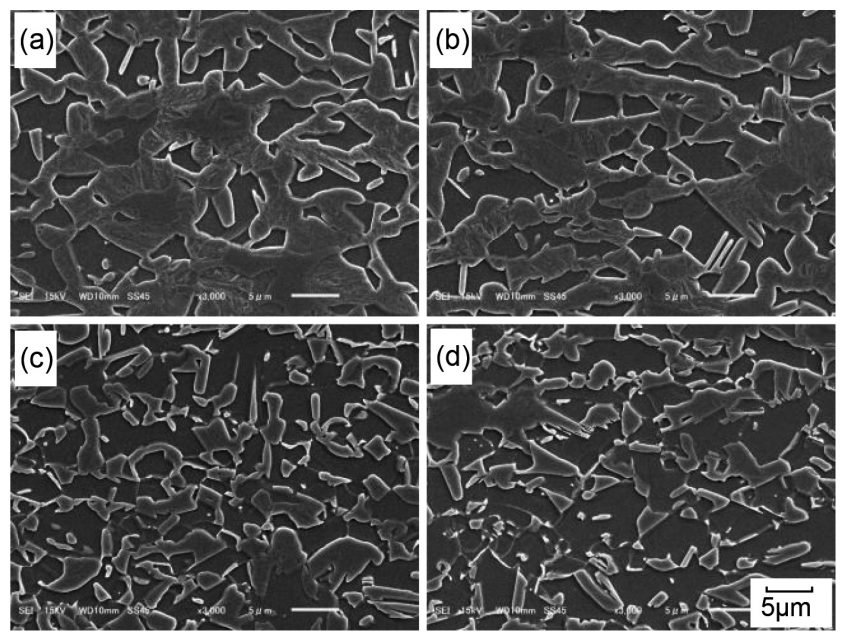

Fig. 8. SEM images of specimens for Pattern B with $T_{\mathrm{a}}=800^{\circ} \mathrm{C}$ $(1073 \mathrm{~K})$ and $t_{\mathrm{a}}=1.8 \mathrm{ks}$ at (a) $T_{\mathrm{q}}=800^{\circ} \mathrm{C}(1073 \mathrm{~K})$, (b) $T_{\mathrm{q}}=700^{\circ} \mathrm{C}(973 \mathrm{~K}),(\mathrm{c}) T_{\mathrm{q}}=600^{\circ} \mathrm{C}(873 \mathrm{~K})$ and (d) $T_{\mathrm{q}}=$ $400^{\circ} \mathrm{C}(673 \mathrm{~K})$.
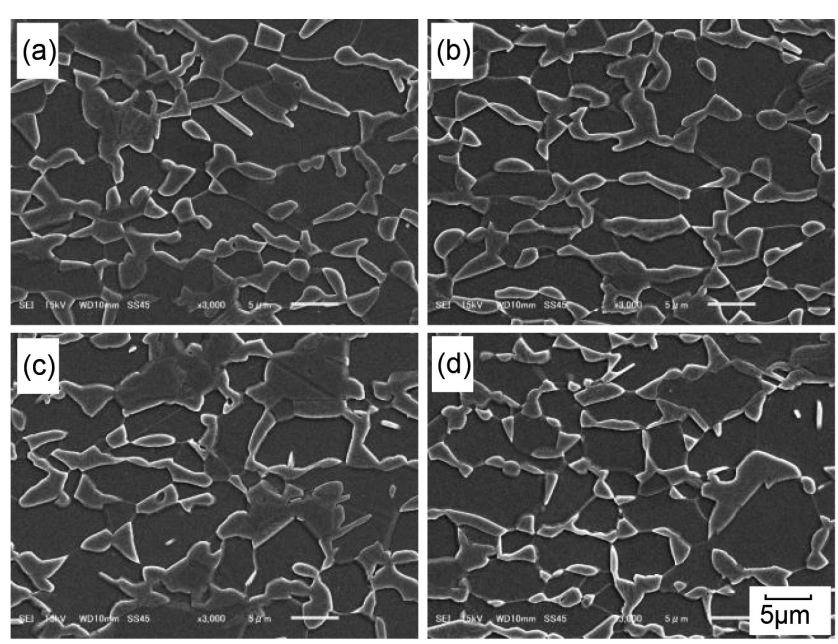

Fig. 9. SEM images of specimens for Pattern $\mathrm{B}$ with $T_{\mathrm{a}}=740^{\circ} \mathrm{C}$ $(1013 \mathrm{~K})$ and $t_{\mathrm{a}}=14.4 \mathrm{ks}$ at (a) $T_{\mathrm{q}}=740^{\circ} \mathrm{C}(1013 \mathrm{~K}),(\mathrm{b})$ $T_{\mathrm{q}}=700^{\circ} \mathrm{C}(973 \mathrm{~K}),(\mathrm{c}) T_{\mathrm{q}}=600^{\circ} \mathrm{C}(873 \mathrm{~K})$ and $(\mathrm{d}) T_{\mathrm{q}}=$ $400^{\circ} \mathrm{C}(673 \mathrm{~K})$.
積率は $T_{\mathrm{q}}=800^{\circ} \mathrm{C}$ の 0.35 から水焼入れ温度の低下により増 加し, $T_{\mathrm{q}}=400^{\circ} \mathrm{C}$ で 0.67 となる。特に, $700-600{ }^{\circ} \mathrm{C}$ の温度域 において, フェライト体積率の増加が顕著に生じる。一方, $T_{\mathrm{a}}=740^{\circ} \mathrm{C}, t_{\mathrm{a}}=14.4 \mathrm{ks}$ の焼鈍条件では, 水焼入れ温度の変 化に伴うフェライト体積率の変化はほとんど生じず, 全て の条件で 0.67 に近い值となる。

Fig. 11 に $T_{\mathrm{a}}=800^{\circ} \mathrm{C}, t_{\mathrm{a}}=1.8 \mathrm{ks}, T_{\mathrm{q}}=800-400^{\circ} \mathrm{C}$ の各条件 で熱処理した試料のSEM像，およびSEM像と同じ視野に おける $\mathrm{C}, \mathrm{Mn}, \mathrm{Si}$ の濃度の二次元マッピングを示す。 $T_{\mathrm{q}}=$ $800^{\circ} \mathrm{C}$ およ゙ $700^{\circ} \mathrm{C}$ では，オーステナイト中のCおよびフェ ライト中の Si は均一に分布するのに対して，オーステナ イト中の Mn は不均一な分布となる。水焼入れ温度の低下 に伴いフェライト体積率が増加し, オーステナイト体積

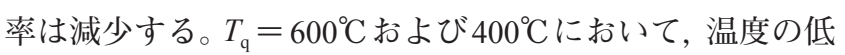
下に伴う Mn および $\mathrm{Si}$ の分布の変化はほとんど認められな いのに対して, Cの分布が不均一となり，オーステナイト 中の $\mathrm{C}$ 濃度が $T_{\mathrm{q}}=800^{\circ} \mathrm{C}$ および $700^{\circ} \mathrm{C}$ に対して高くなる。 $T_{\mathrm{q}}=400^{\circ} \mathrm{C}$ に打いてオーステナイト中のC濃度は, 約 0.30 mass\%の分布が認められる。Fig.11の (c2) と (c3) および (d2) と（d3）を比べると, C濃度の高い領域と $\mathrm{Mn}$ 濃度の高 い領域が必ずしも一致せず，後者の方が広範囲となってい ることが分かる。 $T_{\mathrm{a}}=740^{\circ} \mathrm{C}, t_{\mathrm{a}}=14.4 \mathrm{ks}$ の焼鈍条件につい て, 同様に $T_{\mathrm{q}}=740^{\circ} \mathrm{C}$ と $T_{\mathrm{q}}=400^{\circ} \mathrm{C}$ の SEM像および $\mathrm{SEM}$ 像 と同じ視野における $\mathrm{C}, \mathrm{Mn}, \mathrm{Si}$ の濃度の二次元マッピング を比較したものを Fig.12に示す。Fig.11 とは異なり, 水焼入 れ温度による各相の体積率および各溶質元素濃度の分布の 明瞭な変化は認められない。これは，この焼鈍条件におい て緩冷却時のフェライト変態が抑制されていることを意味 する。このような Fig.11 と Fig.12の差異について, 4・2節 で考察する。

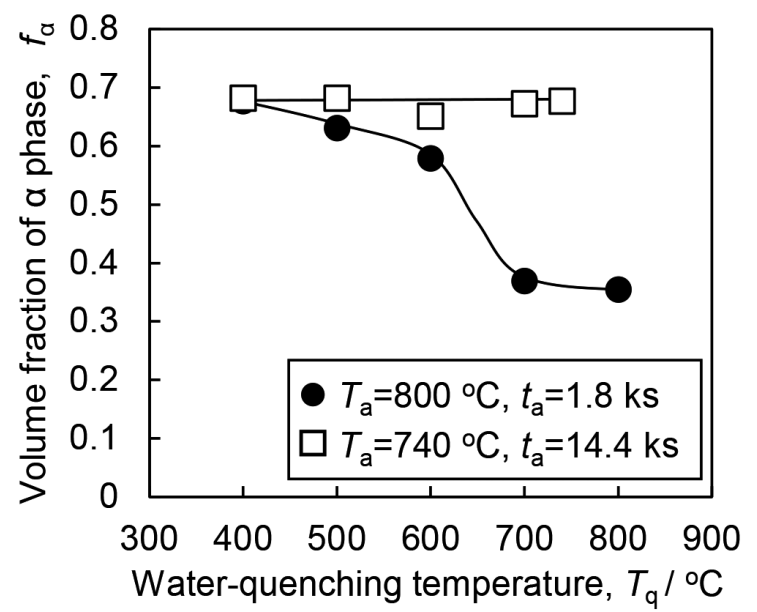

Fig. 10. Dependence of volume fraction $f_{\mathrm{a}}$ of $\alpha$ phase on quenching temperature $T_{\mathrm{q}}$. Result for $T_{\mathrm{a}}=800^{\circ} \mathrm{C}(1073$ $\mathrm{K})$ and $t_{\mathrm{a}}=1.8 \mathrm{ks}$ is indicate as solid circles, and that for $T_{\mathrm{a}}=740^{\circ} \mathrm{C}(1013 \mathrm{~K})$ and $t_{\mathrm{a}}=14.4 \mathrm{ks}$ is represented as open squares. 

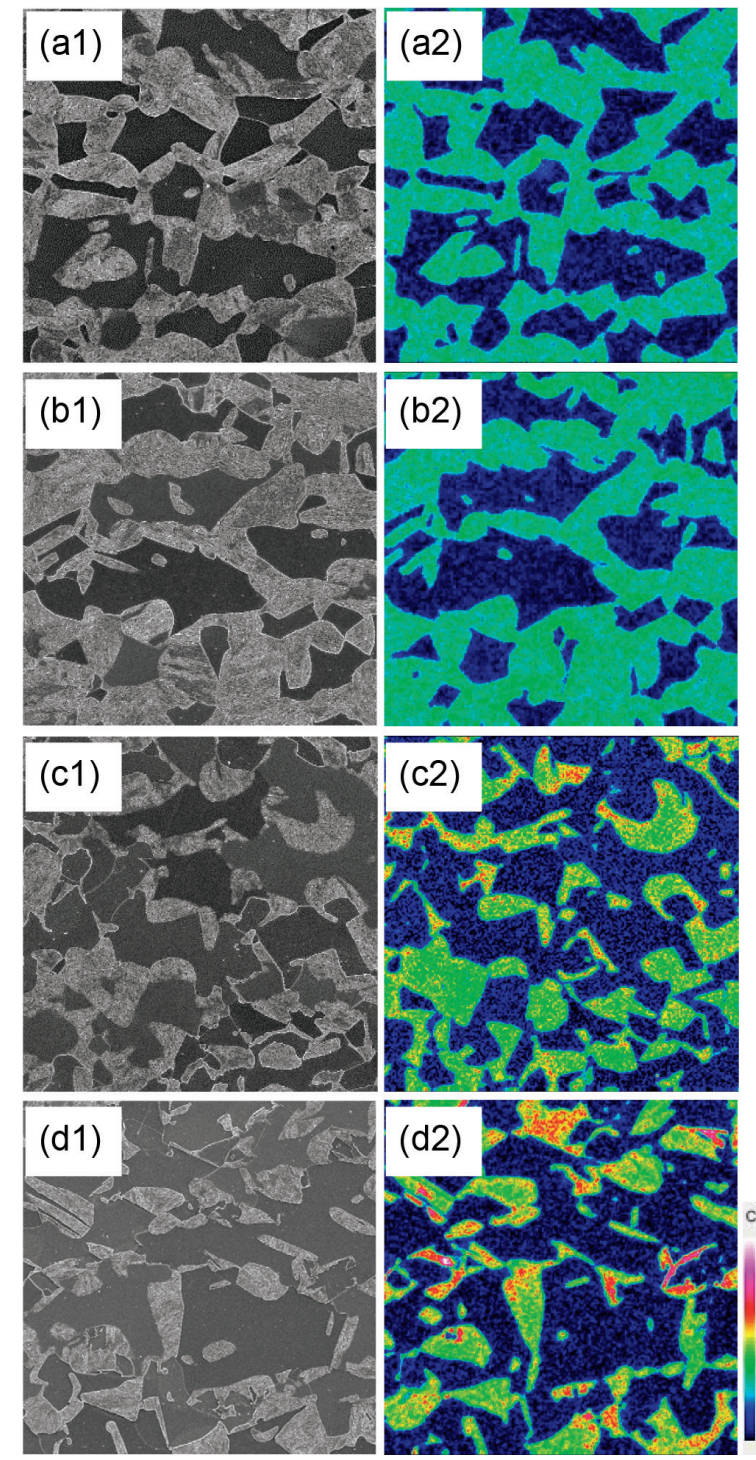
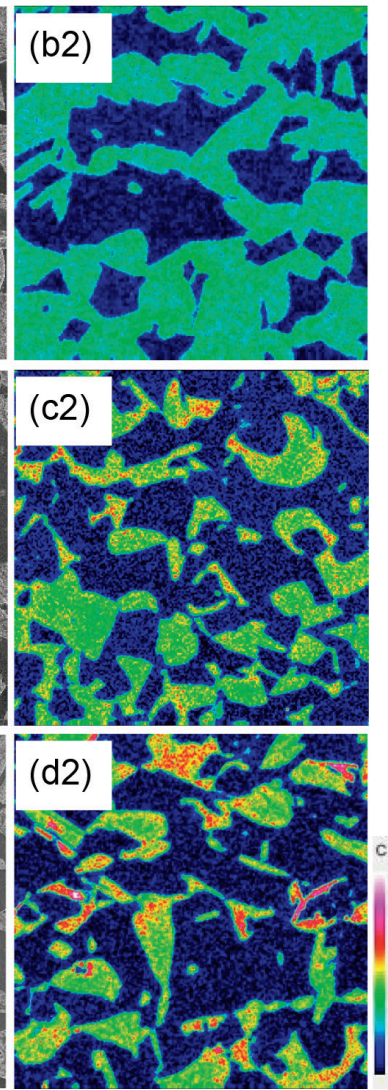
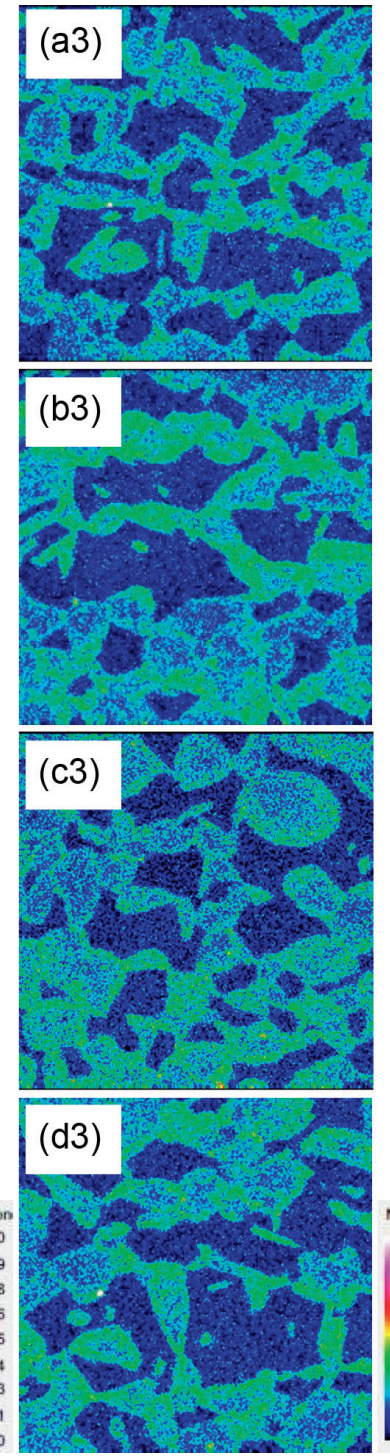
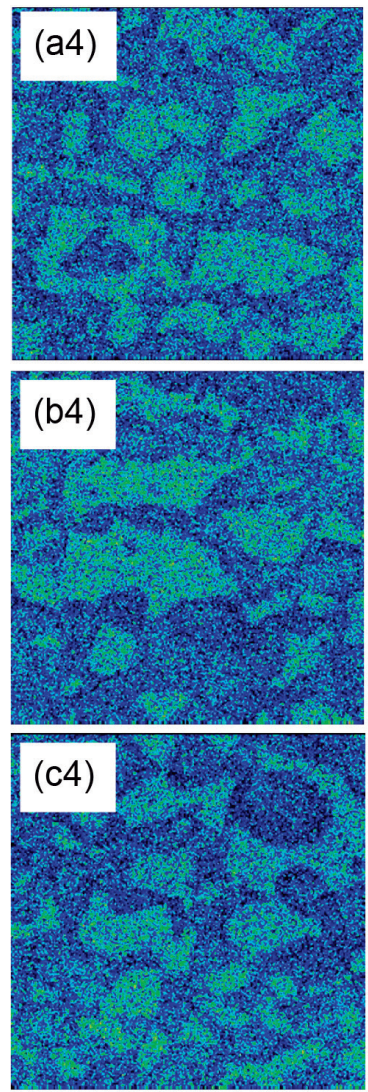

(d4)

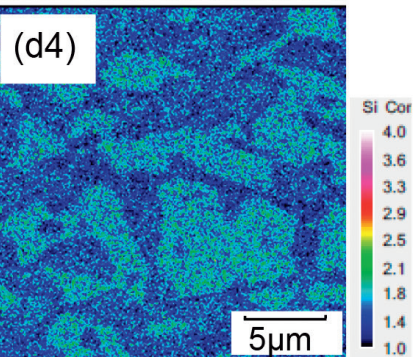

Fig. 11. (a1, b1, c1, d1) SEM images and (ai, bi, ci, di) elemental mappings of $\mathrm{C}, \mathrm{Mn}$ and $\mathrm{Si}$ for $i=2,3$ and 4, respectively, of specimens for Pattern B with $T_{\mathrm{a}}=800^{\circ} \mathrm{C}(1073 \mathrm{~K})$ and $t_{\mathrm{a}}=1.8 \mathrm{ks}$ at (a) $T_{\mathrm{q}}=800^{\circ} \mathrm{C}(1073 \mathrm{~K}),(\mathrm{b}) T_{\mathrm{q}}=700^{\circ} \mathrm{C}(973 \mathrm{~K}),(\mathrm{c}) T_{\mathrm{q}}=$ $600^{\circ} \mathrm{C}(873 \mathrm{~K})$ and (d) $T_{\mathrm{q}}=400^{\circ} \mathrm{C}(673 \mathrm{~K})$.
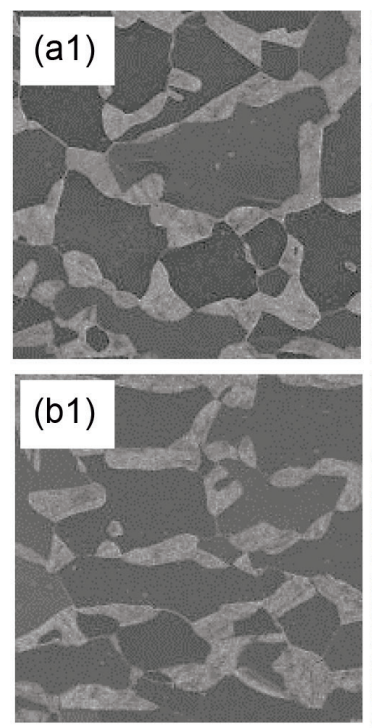
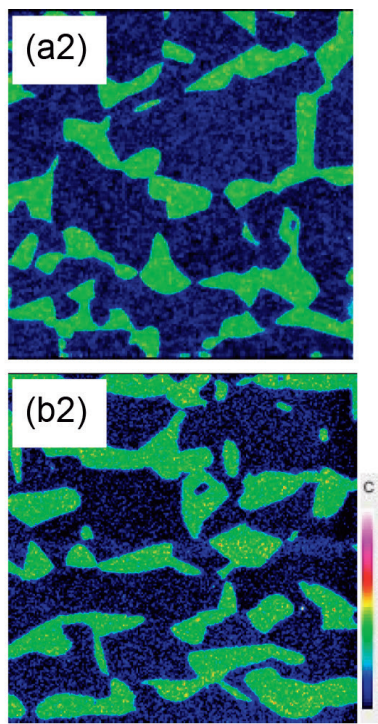
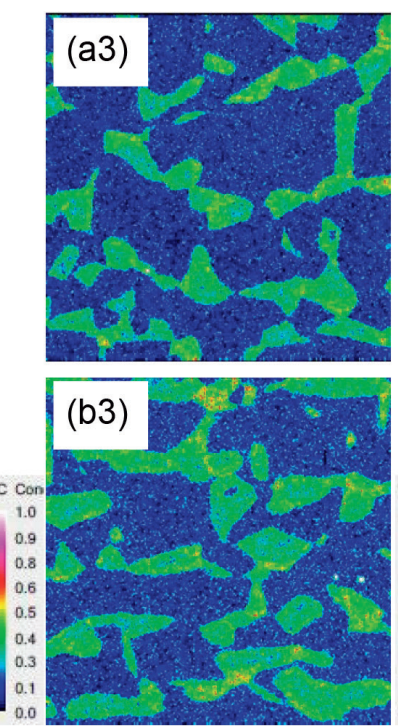
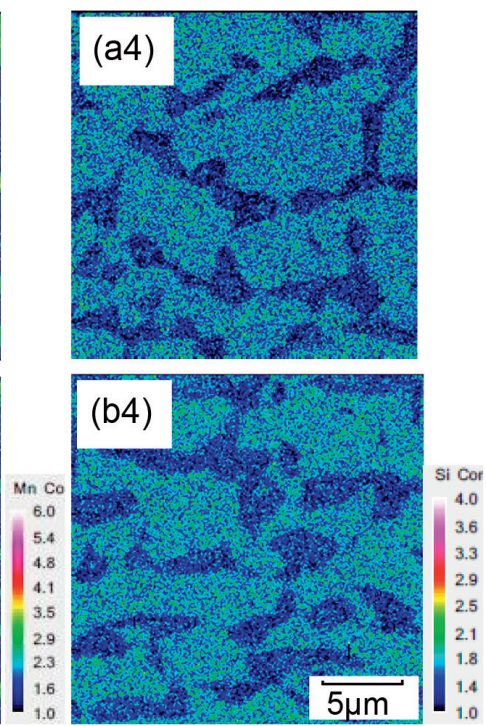

Fig. 12. (a1, b1) SEM images and ( $a i, b i)$ elemental mappings of $\mathrm{C}, \mathrm{Mn}$ and $\mathrm{Si}$ for $\mathrm{i}=2,3$ and 4 , respectively, of specimens for Pattern B with $T_{\mathrm{a}}=740^{\circ} \mathrm{C}(1013 \mathrm{~K})$ and $t_{\mathrm{a}}=14.4 \mathrm{ks}$ at (a) $T_{\mathrm{q}}=740^{\circ} \mathrm{C}(1013 \mathrm{~K})$ and (b) $T_{\mathrm{q}}=400^{\circ} \mathrm{C}(673 \mathrm{~K})$. 


\section{4. 考察}

\section{$4 \cdot 1$ 二相域焼鈍時の逆変態および溶質元素分配の 計算シミュレーション}

二相域焼鈍時の逆変態挙動およびフェライトとオース テナイトへの溶質元素の分配挙動について, DICTRA ${ }^{\circledR} を$ 用いた計算機シミュレーションを行った。DICTRAは局所 平衡を前提として拡散方程式を解くソフトウェアであり, Thermo-Calc と連動して動作するため，Thermo-Calcの熱 力学データを使用できる。今回の計算では, 熱力学データ ベースはTCFE7を用い，拡散データベースはMOB2を用い た。二相域焼鈍時の近接するフェライト粒の中央位置の平 均距離が約 $5 \mu \mathrm{m}$ であったことから，計算に用いたセルは 5 $\mu \mathrm{m}$ の矩形形状とした。

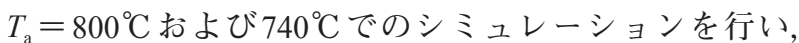
フェライトとオーステナイトの二相組織を初期組織とし て，時間経過とともにオーステナイトが左側から成長する ように設定した。 $T_{\mathrm{a}}=800^{\circ} \mathrm{C}$ のミュレーションでは，実 験的に求めた $800^{\circ} \mathrm{C}$ 保持開始時のオーステナイトの平均粒 径の $1 / 2$ の值として, 初期オーステナイトの厚さを $2 \mu \mathrm{m}$ で 設定した。一方, $T_{\mathrm{a}}=740^{\circ} \mathrm{C}$ の実験では, $740^{\circ} \mathrm{C}$ 到達時には オーステナイトが認められなかったことから， $T_{\mathrm{a}}=740^{\circ} \mathrm{C}$ のシミュレーションでは, $1 \times 10^{-3} \mu \mathrm{m}$ の非常に薄いオー ステナイトを初期組織として設定した。初期の元素の分布 状態について，Mnおよび $\mathrm{Si}$ 濃度はセル内で均一とし，Cは $T_{\mathrm{a}}=800^{\circ} \mathrm{C}$ のミュレーションのみフェライトとオーステ ナイトに分配した条件を設定した。

計算機シミュレーションで求めた $T_{\mathrm{a}}=800^{\circ} \mathrm{C}$ および $740^{\circ} \mathrm{C}$ における焼鈍時間とオーステナイト体積率との関 係を，実験結果と比較して Fig. 13 に示す。 $T_{\mathrm{a}}=800^{\circ} \mathrm{C} て ゙ は ，$ 実験結果と計算結果とで良好な相関が認められる。一方, $T_{\mathrm{a}}=740^{\circ} \mathrm{C}$ では，実験結果に対して計算結果の方がオース テナイト体積率の増加が短時間で生じている。計算で求め た各条件でのCおよびMn濃度のセル内の分布を Fig.14に
示す。Fig.14 (a) および（b）は，それぞれ $T_{\mathrm{a}}=800^{\circ} \mathrm{C} に お ~$ けるCおよびMn濃度の分布を示し, Fig.14 (c) および (d) は, $T_{\mathrm{a}}=740^{\circ} \mathrm{C}$ における $\mathrm{C}$ おび $\mathrm{Mn}$ 濃度の分布を示す。各 温度での保持により，七ルの左側に設定したオーステナイ トが時間とともに右側のフェライトの方に成長し，Cおよ びMnはオーステナイトとフェライトに分配する。フェラ イトおよびオーステナイトの各相内に扎いて，Cはほぼ均 一に分布しているのに対して, Mnについては各相内での 濃度分布が認められる。オーステナイト粒内に打ける $\mathrm{Mn}$ 濃度 $\left(C^{\gamma}{ }_{\mathrm{Mn}}\right)$ は，オーステナイト/フェライト界面付近にお いて相の内部よりも高い值を示す。オーステナイト内の各 位置における $C^{\gamma}{ }_{\mathrm{Mn}}$ は保持時間によって変化しないが，保 持時間の増加によるオーステナイトの成長に伴い，オース テナイト/フェライト界面の $\mathrm{Mn}$ 濃度 $\left(C^{\gamma / \alpha}{ }_{\mathrm{Mn}}\right)$ は高くなる。 高精度FE-EPMA 分析での測定結果において, $T_{\mathrm{a}}=800^{\circ} \mathrm{C}$, $t_{\mathrm{a}}=1.8 \mathrm{ks}$ の焼鈍条件における $C^{\gamma / \alpha}{ }_{\mathrm{Mn}}$ は約 2.5 mass $\%$ と高い 值となっていたのに対して，オーステナイト/フェライト 界面から離れた位置での $C^{\gamma}{ }_{\mathrm{Mn}}$ は約 $1.7 \mathrm{mass} \%$ であり，鋼の $\mathrm{Mn}$ 組成に近い值となっていた。このように, $T_{\mathrm{a}}=800^{\circ} \mathrm{C} に$ おける計算結果である Fig.14 (a) および (b) は実験結果と 良好な相関を示す。一方, $T_{\mathrm{a}}=740^{\circ} \mathrm{C}, t_{\mathrm{a}}=14.4 \mathrm{ks}$ の焼鈍条 件での高精度 FE-EPMA 分析の測定結果では, $C^{\gamma}{ }_{\mathrm{Mn}}$ はオー ステナイト結晶粒の中央付近においても $2.0 \mathrm{mass} \%$ 以上の 高い值であったのに対して, Fig.14 (d) に示す $C^{\gamma}{ }_{\mathrm{Mn}}$ はオー ステナイト/フェライト界面から離れた位置に打いて約 1.7 $\operatorname{mass} \%$ となっている。このように, $T_{\mathrm{a}}=740^{\circ} \mathrm{C}$ の条件にお いては, Mn濃度の分布が計算結果と実験結果とで乘離し た。

Sun and Pugh ${ }^{13)}$ は，二相域焼鈍においてMnはフェライ トからオーステナイト/フェライト界面に拡散し，Mnリッ チなリムが形成された後，最終的にオーステナイト中の $\mathrm{Mn}$ の拡散によりオーステナイト内の Mn濃度が均一にな

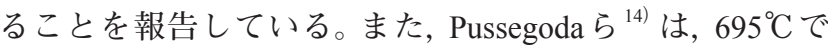
$\mathrm{Mn}$ リッチなリムが形成された後，数時間で Mnがオーステ
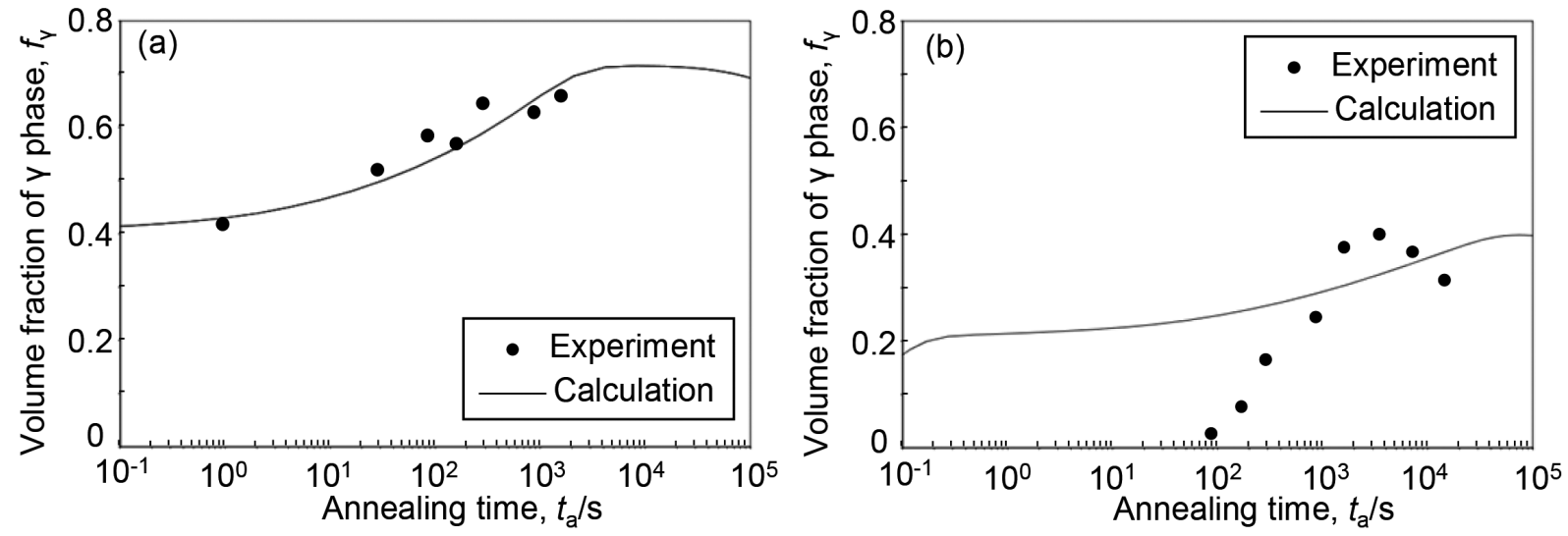

Fig. 13. Calculations by DICTRA ${ }^{\circledR}$ for dependence of volume fraction $f_{\gamma}$ of $\gamma$ phase on annealing time shown as solid curves: (a) $T_{\mathrm{a}}=$ $800^{\circ} \mathrm{C}(1073 \mathrm{~K})$ and (b) $T_{\mathrm{a}}=740^{\circ} \mathrm{C}(1013 \mathrm{~K})$. Experimental results are indicated as solid circles. 
ナイト粒の中央部まで拡散することを報告している。彼ら は, $\mathrm{Mn}$ 濃度の増加および格子欠陷の存在によりオーステ ナイト中の Mnの拡散係数が高くなり，上記のような短時 間で Mnの均一化が生じる可能性を提示している。

Fig. 15 に, $T_{\mathrm{a}}=800^{\circ} \mathrm{C}$ および $740^{\circ} \mathrm{C}$ での保持開始初期の状 態を確認することを目的に, 各温度で短時間保持した後, 水焼入れした試料のSEM像および各元素濃度の二次元 マッピングを示す。Fig.15 (a) は $T_{\mathrm{a}}=800^{\circ} \mathrm{C}, t_{\mathrm{a}}=1 \mathrm{~s}$, Fig. 15 (b) は $T_{\mathrm{a}}=740^{\circ} \mathrm{C}, t_{\mathrm{a}}=1 \mathrm{~s}$,Fig. 15 (c) は $T_{\mathrm{a}}=740^{\circ} \mathrm{C}, t_{\mathrm{a}}=900 \mathrm{~s}$ の焼鈍条件の結果である。Fig.15（a）において，Cはオース テナイトに濃化しているが, Mn扎よび $\mathrm{Si}$ のオーステナイ トとフェライトへの分配はほとんど生じていない。Fig.15 (b) では，オーステナイトは存在せず，組織はフェライト と球状なセメンタイトからなり, C はセメンタイトが集積 している箇所で高くなっている。一方，Mn濃度は球状の セメンタイトにおける局所的な濃化を除いてほぼ均一に 分布している。Fig.15 (c) では, オーステナイトが生成し, C 打よびMnが共にオーステナイトに濃化している。これ

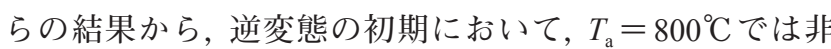
分配でオーステナイトが生成するのに対して, $T_{\mathrm{a}}=740^{\circ} \mathrm{C}$ ではオーステナイトが Mnの分配を伴って生成すると言え る。 $T_{\mathrm{a}}=800^{\circ} \mathrm{C}$ におけるオーステナイトへの $\mathrm{Mn}$ の濃化は, 過去に多く報告 ${ }^{3,13-16)}$ されているように，オーステナイト の生成後の Mnの拡散により生じると考えられる。しかし， $740^{\circ} \mathrm{C}$ での逆変態初期のオーステナイトへの $\mathrm{Mn}$ 濃化は上 記の考え方では説明が困難である。

Fig.16に Fe-1.5 mass\%Si-C-Mn四元系の Feリッチ側の 740 ${ }^{\circ} \mathrm{C}$ における等温断面困を示す。フェライト/オーステナイ 卜二相領域は, 局所平衡理論に基づいて, 不分配局所平衡 (NPLE: NegligiblePartitioning Local Equilibrium) 領域と分配 局所平衡 (PLE: Partitioning Local Equilibrium) 領域とに分 けられる ${ }^{17-21)} 。 T_{\mathrm{a}}=740^{\circ} \mathrm{C}, t_{\mathrm{a}}=1 \mathrm{~s}$ の焼鈍条件で得られた 試料について, FE-EPMA分析で測定したフェライトの化 学組成を Fig.16に白丸として示す。さらに, DICTRAの計 算に沶いて，フェライトの初期状態として設定した化学組 成を黒丸として合わせて示す。白丸がPLE領域に入ってい ることから，フェライトからオーステナイトへの逆変態は PLEモードでMnの分配を伴い生じることになる。Zhang $ら^{22)}$ は，ラスマルテンサイトからの逆変態によるオーステ ナイト生成の速度論的解析および溶質元素の分配につい ての調査を行い, 逆変態の前にMn および $\mathrm{Si}$ がセメンタイ トと母相のフェライトに分配することで逆変態が遅延し, オーステナイトの成長が置換型溶質元素の分配を伴って生 じることを報告している。本研究においては, $T_{\mathrm{a}}=740^{\circ} \mathrm{C}$ でセメンタイトが完全に溶解するのに $900 \mathrm{~s}$ 以上の保持時 間を要し，逆変態によるオーステナイトの生成とセメンタ イトの溶解が同時に生じている。そして, セメンタイトの 存在によりフェライト中のC濃度が低くなり, オーステナ
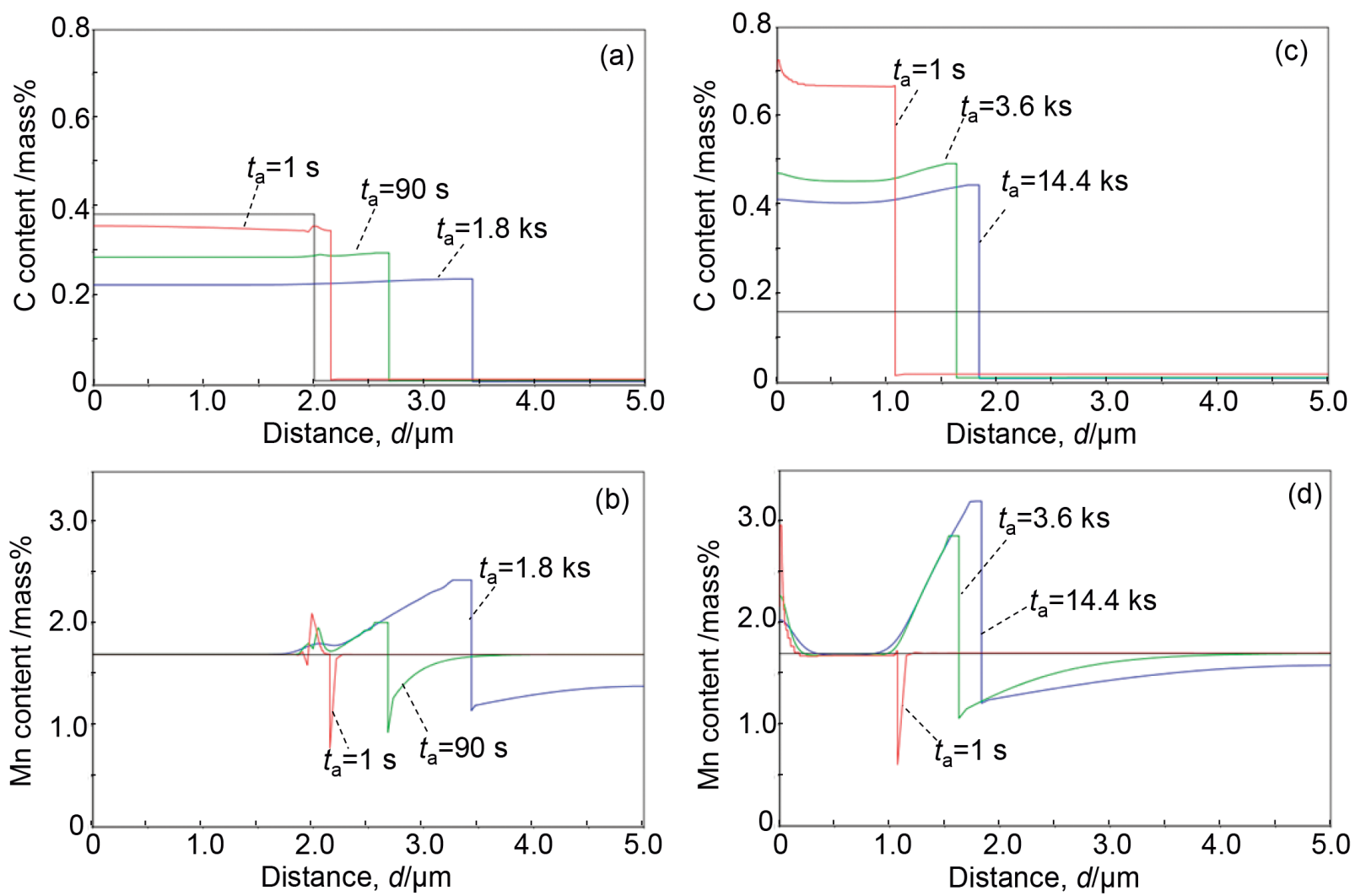

Fig. 14. Calculations by DICTRA ${ }^{\circledR}$ for profiles of $\mathrm{C}$ and Mn contents at various annealing times: (a) $\mathrm{C}$ at $T_{\mathrm{a}}=800^{\circ} \mathrm{C}(1073 \mathrm{~K})$, (b) $\mathrm{Mn}$ at $T_{\mathrm{a}}=800^{\circ} \mathrm{C}(1073 \mathrm{~K}),(\mathrm{c}) \mathrm{C}$ at $T_{\mathrm{a}}=740^{\circ} \mathrm{C}(1013 \mathrm{~K})$ and (d) $\mathrm{Mn}$ at $T_{\mathrm{a}}=740^{\circ} \mathrm{C}(1013 \mathrm{~K})$. (Online version in color.) 
イトの生成がPLEモードで進行する。その結果，逆変態の 初期からオーステナイトにMnが濃化し, オーステナイト 中の $\mathrm{Mn}$ 濃度が結晶粒の中央においても高くなる。

しかし, DICTRAの計算では, セメンタイトの溶解と逆 変態によるオーステナイトの成長を同時に取り扱うのが

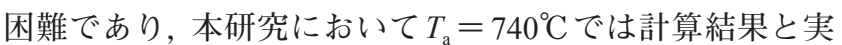
駼結果で乘離が生じた。一方, $T_{\mathrm{a}}=800^{\circ} \mathrm{C} に$ 打いては, 逆変 態の開始前にセメンタイトの溶解が完了することから, 逆 変態挙動が DICTRAで計算できた。上述のように，セメン タイトの溶解が完了せずフェライト中の C 濃度が低い状態 から逆変態が生じる場合, 逆変態はPLEモードで進行し, オーステナイトへの Mnの濃化が逆変態の初期から生じ る。

\section{$4 \cdot 2$ 二相域焼鈍後のフェライト変態モード}

フェライトとオーステナイトの拡散変態の変態モード は, 置換型溶質元素のフェライトとオーステナイトへの分 配挙動により,パラ平衡 (PE：Para- Equilibrium), PLE打よ びNPLEに分類される。PEモードでは置換型溶質元素であ る $\mathrm{Mn}$ や $\mathrm{Si}$ の拡散を伴わず，Cの拡散がフェライト/オース テナイト界面の移動を律速する。一方, PLE扎よびNPLE モードでは，フェライト/オーステナイト界面に打ける局 所的な平衡を保ちながら, 置換型溶質元素の拡散により界 面移動が律速される。PLEモードに打いては，Cと置換型 溶質元素が共にフェライトとオーステナイトに分配するの
に対して, NPLEモードでは置換型溶質元素濃度はフェラ イト/オーステナイト界面に打いてのみ局所的に変化し， フェライトとオーステナイトへの巨視的な分配は生じず, フェライトとオーステナイト中の置換型溶質元素濃度は一

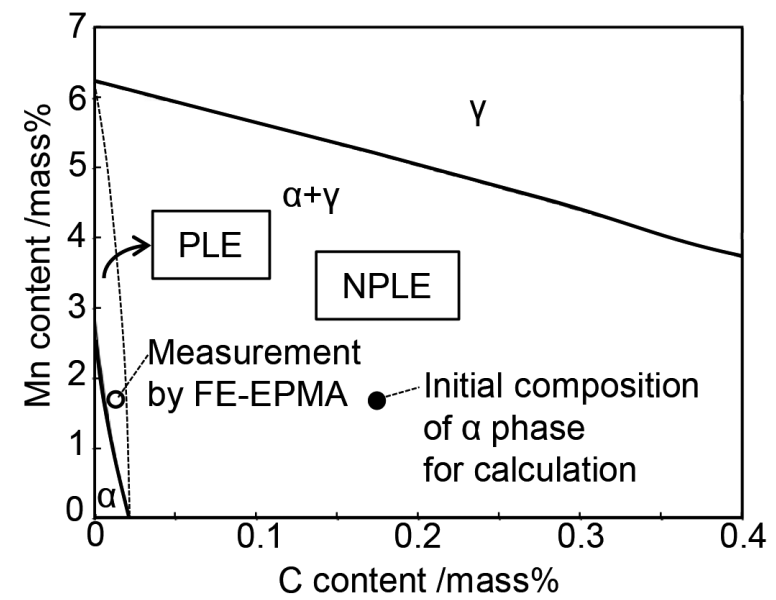

Fig. 16. Isothermal section at $740^{\circ} \mathrm{C}(1013 \mathrm{~K})$ of phase diagram in quasi-ternary Fe-1.5Si-C-Mn system. The $\alpha+\gamma$ twophase region is divided into the PLE and NPLE regions for the reverse transformation. Chemical composition of $\alpha$ phase in specimen with $T_{\mathrm{a}}=740^{\circ} \mathrm{C}(1013 \mathrm{~K})$ and $t_{\mathrm{a}}=1 \mathrm{~s}$ measured by FE-EPMA is shown as an open circle, and initial chemical composition of $\alpha$ phase used for kinetic calculation in Fig. 14 is indicated as a solid circle.
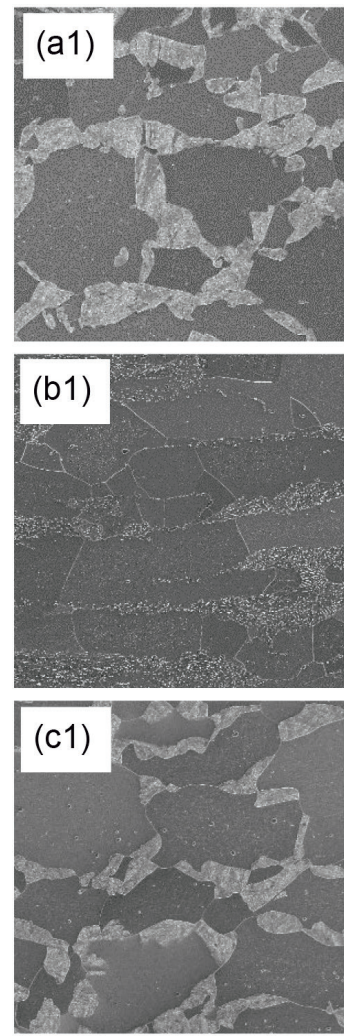
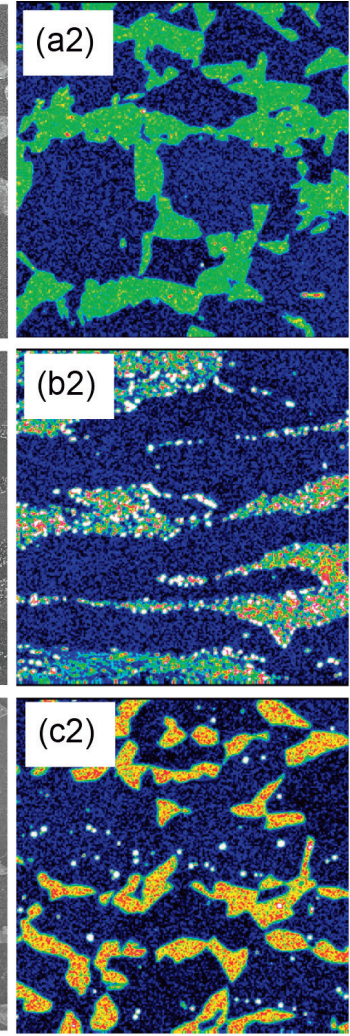
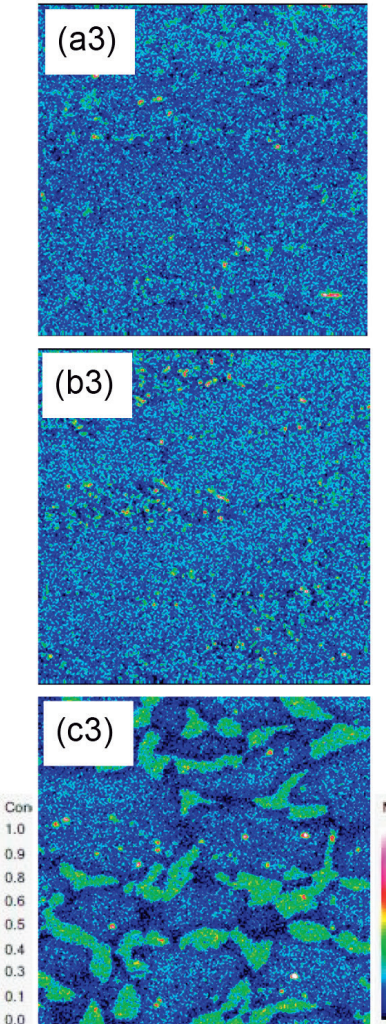
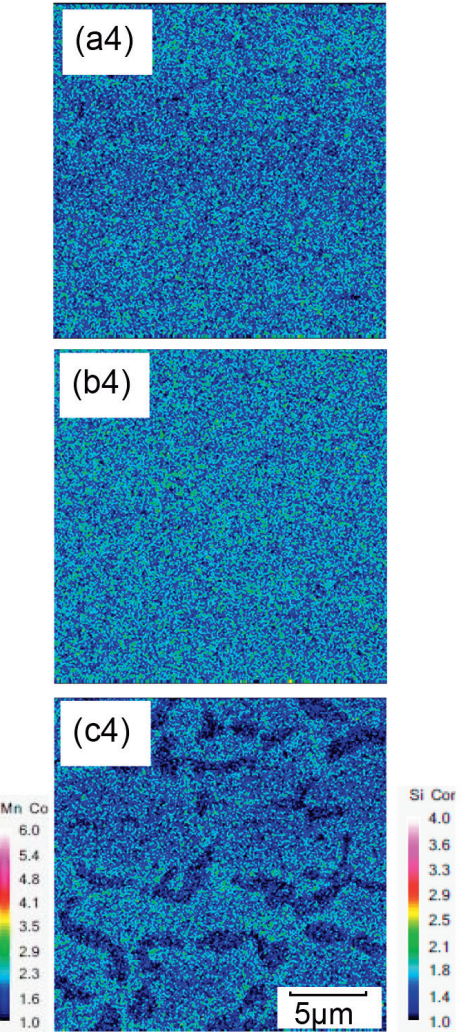

Fig. 15. (a1, b1, c1) SEM images and (ai, bi, ci) elemental mappings of C, Mn and Si for $i=2,3$ and 4, respectively, of specimens with various annealing temperatures and times: (a) $T_{\mathrm{a}}=800^{\circ} \mathrm{C}(1073 \mathrm{~K})$ and $t_{\mathrm{a}}=1 \mathrm{~s}$, (b) $T_{\mathrm{a}}=740^{\circ} \mathrm{C}(1013 \mathrm{~K})$ and $t_{\mathrm{a}}=1 \mathrm{~s}$ and (c) $T_{\mathrm{a}}$ $=740^{\circ} \mathrm{C}(1013 \mathrm{~K})$ and $t_{\mathrm{a}}=900 \mathrm{~s}$. 
定となる。PLEモードでは拡散速度の遅い置換型溶質元素 の分配に律速されフェライト変態が進行することから, PE モードやNPLEモードに対してフェライト変態が顕著に遅 延する。

Fig. 8 およびFig. 11 に示した $T_{\mathrm{a}}=800^{\circ} \mathrm{C}, t_{\mathrm{a}}=1.8 \mathrm{ks}$ におけ る, 冷却時の各温度から水焼入れした試料のフェライト とオーステナイトの化学組成を Fig.17に示す。Fig.17 (a), (b)，(c) および (d) はそれぞれ $T_{\mathrm{q}}=800^{\circ} \mathrm{C}, 700^{\circ} \mathrm{C}, 600^{\circ} \mathrm{C}$ および $400^{\circ} \mathrm{C}$ の結果である。

ここで, 横軸は C 濃度, 縦軸は Mn 濃度であり, フェライ トとオーステナイトの複数の結晶粒について粒内を $0.09 \mu$ $\mathrm{m}$ の間隔で高精度FE-EPMAのライン分析を行って求めた。 $\mathrm{Si}$ はフェライト安定化元素で，二相域焼鈍後のフェライト 変態を促進する。しかし，3・1節で示したように，二相域 焼鈍時の $\mathrm{Si}$ のフライトとオーステナイトへの分配の割 合はCやMnに比べて小さい。したがって，ここではCと $\mathrm{Mn}$ の分配の影響に着目して検討を行った。

Fig.17 (a) に示す $T_{\mathrm{q}}=800{ }^{\circ} \mathrm{C} に$ にいて, Cおよび $\mathrm{Mn}$ 濃 度は共にオーステナイトよりもフェライトの方が低い。 Fig.17（b）に示す $T_{\mathrm{q}}=700^{\circ} \mathrm{C}$ では, $\mathrm{Mn}$ 濃度の高いフェラ イトの生成が認められ，オーステナイトについてはMn濃 度は変わらずにC濃度が高くなっている。 $\mathrm{Mn}$ 濃度が高い フェライトは，二相域焼鈍後の緩冷却時に生成したと考え られる。以後，二相域焼鈍時に生成するフェライトを焼鈍 フェライト，緩冷却時に生成するフェライトを変態フェラ イトとする。 $T_{\mathrm{q}}=800^{\circ} \mathrm{C}$ から $T_{\mathrm{q}}=400^{\circ} \mathrm{C}$ まで低下するのに 伴い, オーステナイト中の化学組成は Mn濃度の変化は生 じず，平均 C濃度は 0.27 から 0.5 mass\%に増加する。これ は，緩冷却時に Mnの分配は伴わずに，Cがオーステナイト
に濃化していることを示す。

Fe-1.5 mass\%Si-Mn-C四元系の各温度における等温断 面困に，高精度FE-EPMA分析で測定したオーステナイ トの化学組成を併せたものを Fig.18に示す。ここで, $T_{\mathrm{a}}=$ $800{ }^{\circ} \mathrm{C}, t_{\mathrm{a}}=1.8 \mathrm{ks}$ の焼鈍条件の結果は黒丸, $T_{\mathrm{a}}=740{ }^{\circ} \mathrm{C}$, $t_{\mathrm{a}}=14.4 \mathrm{ks}$ の焼鈍条件の結果は白四角で示し, Fig.18 (a), (b)，(c) および (d) は，それぞれ $T_{\mathrm{q}}=800^{\circ} \mathrm{C}, 740^{\circ} \mathrm{C}, 600^{\circ} \mathrm{C}$ 扎よび $400^{\circ} \mathrm{C}$ の結果である。Fig. 18 において, フェライト/ オーステナイト二相領域をフェライト変態の PLEと NPLE 領域とに分けている。PLE/NPLEの境界線は, Fig.16に示し た逆変態のものに対して, フェライト変態では高 $\mathrm{C}$ 側に位 置する。Fig.18 (a) および (b) において, FE-EPMAで測定 したオーステナイトの化学組成である黒丸および白四角 はいずれもPLE領域に入っている。Fig.18 (c) に示す $T_{\mathrm{q}}=$ $700^{\circ} \mathrm{C}$ の条件では, 白四角のプロットはPLE領域のままな のに対して，黒丸のプロットはPLE/NPLE境界に位置する ようになり, Fig.18 (d) に示す $T_{\mathrm{q}}=600^{\circ} \mathrm{C}$ の条件において はどちらの焼鈍条件のプロットも PLE/NPLE境界に位置す るようになる。温度の低下に伴いフェライト変態のNPLE 領域は高 $\mathrm{C}$ 高 $\mathrm{Mn}$ 側に拡大し, 高温域ではPLEモードとな る化学組成のオーステナイトにおいて, 温度の低下により NPLEモードに移行するようになる。PLEモードから NPLE モードに遷移する温度は, $T_{\mathrm{a}}=800^{\circ} \mathrm{C}, t_{\mathrm{a}}=1.8 \mathrm{ks}$ の焼鈍条 件では約 $700^{\circ} \mathrm{C}$ で, $T_{\mathrm{a}}=740^{\circ} \mathrm{C}, t_{\mathrm{a}}=14.4 \mathrm{ks}$ の焼鈍条件では 約 $600^{\circ} \mathrm{C}$ とな。

Fig.11 (d1)，(d2) および $(\mathrm{d} 3)$ で示した $T_{\mathrm{a}}=800^{\circ} \mathrm{C}, t_{\mathrm{a}}=1.8$ $\mathrm{ks}, T_{\mathrm{q}}=400^{\circ} \mathrm{C}$ の試料の $\mathrm{SEM}$ 像と, C および $\mathrm{Mn}$ 濃度の二次 元マッピングを Fig.19として再度示す。Fig.19 (a) のSEM 像でフェライトと判別できる領域と C濃度が低い領域は (a)

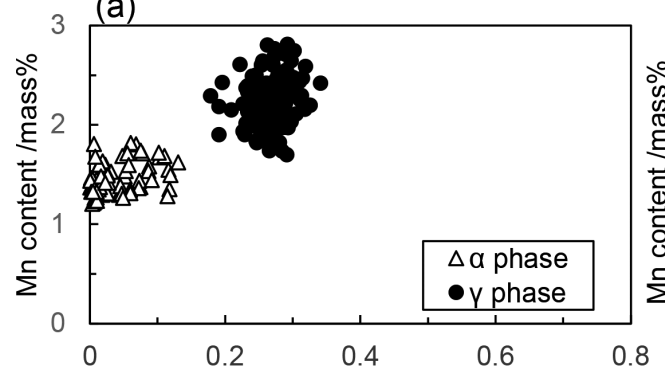

(c)

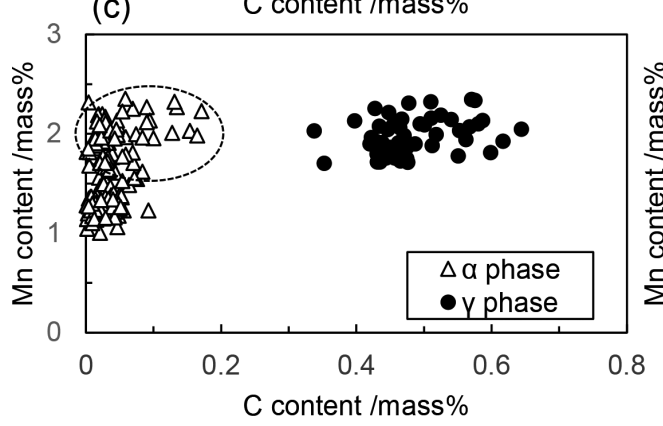

(b)

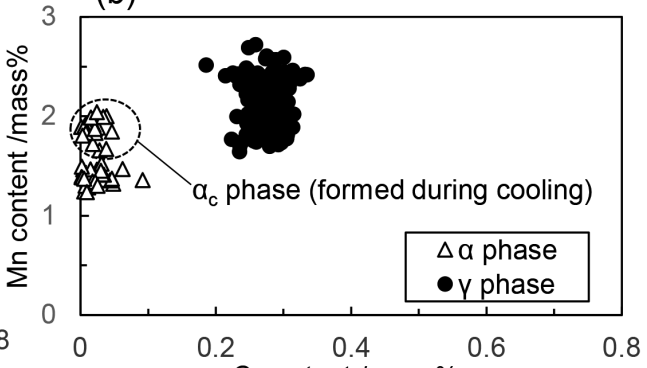

(d)

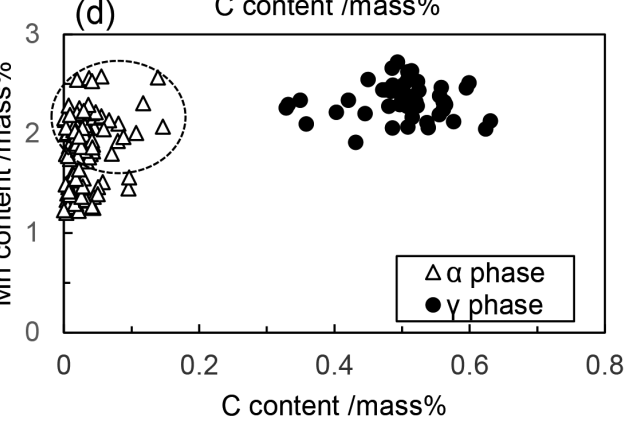

Fig. 17. Chemical compositions of $\alpha$ and $\gamma$ phases for specimens in Figs. 8 and 11 are plotted as open triangles and solid circles, respectively: (a) $T_{\mathrm{q}}=800^{\circ} \mathrm{C}(1073 \mathrm{~K})$, (b) $T_{\mathrm{q}}=700^{\circ} \mathrm{C}(973 \mathrm{~K})$, (c) $T_{\mathrm{q}}=600^{\circ} \mathrm{C}(873 \mathrm{~K})$ and (d) $T_{\mathrm{q}}=400^{\circ} \mathrm{C}(673 \mathrm{~K})$. 
ほぼ一致しているのに対して, Mnについては高 Mn 濃度 のフェライトと低 $\mathrm{Mn}$ 濃度のフェライトが存在している。 Fig.19の試料の水焼入れ温度 $T_{\mathrm{q}}$ は $400^{\circ} \mathrm{C}$ で, PLE/NPLE遷移 温度よりも低いことから, 高 $\mathrm{Mn}$ 濃度のフェライトは緩冷 却中にNPLEモードで生成した変態フェライトで，低 Mn 濃度のフェライトは焼鈍フェライトと考えられる。Fig.19 (a)に扔いて，変態フェライトを矢印で示しているが，そ れらは隣接する焼鈍フェライトと結晶粒界を有さず1つの

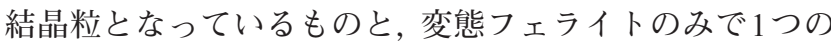
結晶粒となっているものがある。前者を破線の矢印で示
し, 後者を実線の矢印で示している。変態フェライトは二 相域焼鈍後の緩冷却時に, 焼鈍フェライトからのエピタキ シャル成長により生成することが報告されている ${ }^{23-25)}$ 。

エピタキシャル成長により生成した変態フェライトと焼 鈍フェライトは同一の方位を持つ一つの結晶粒となり，そ の間に結晶粒界は存在しない。しかし，本研究においては， エピタキシャルフェライトだけでなく, 焼鈍フェライトと 結晶粒界を有する変態フェライトが認められた。Fig.19よ り, 変態フェライトはオーステナイト中で比較的 Mn 濃度 が低い領域において生成する傾向となっていることが分か (a)
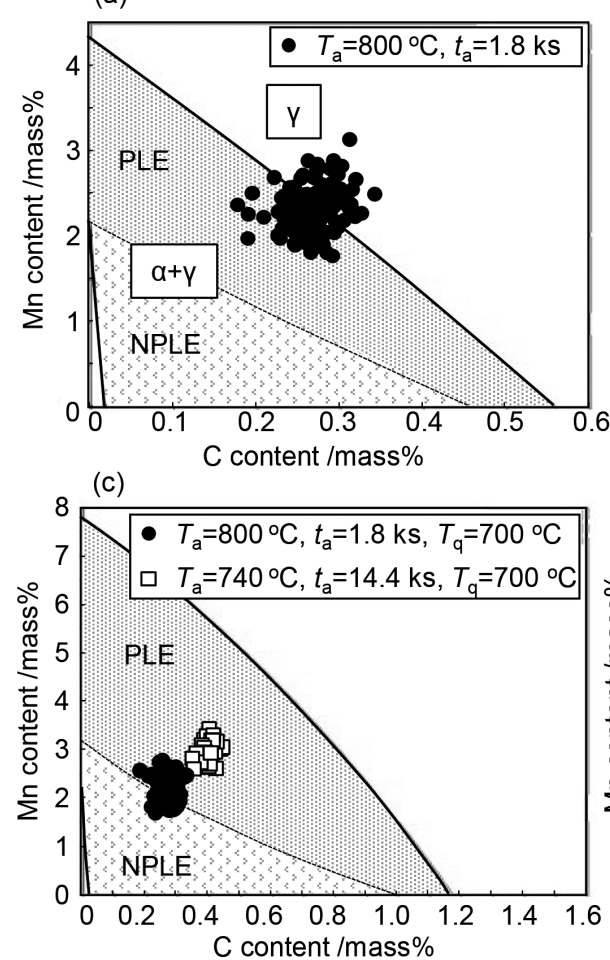

(b)
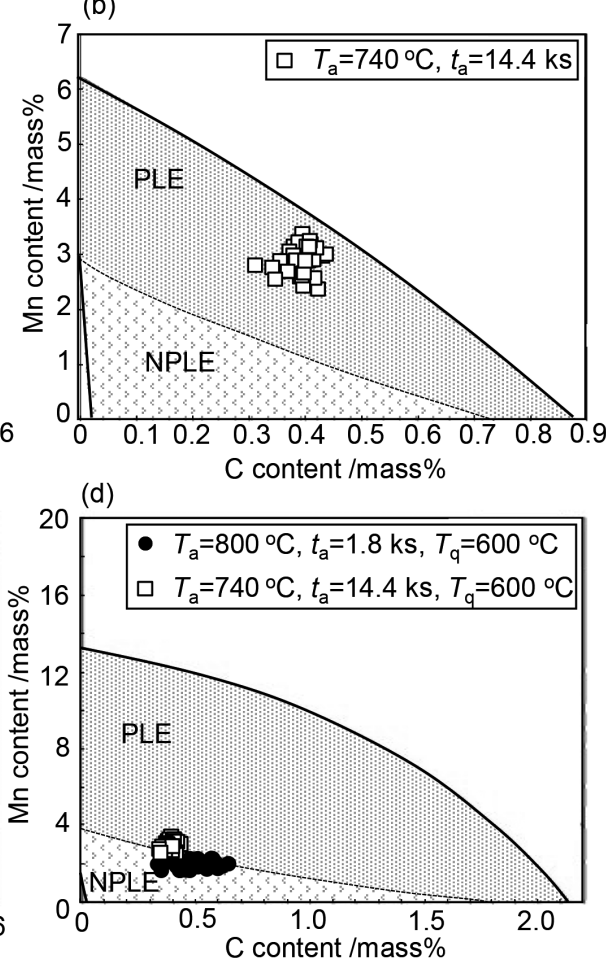

Fig. 18. Isothermal sections at various temperatures of phase diagram in quasi-ternary $\mathrm{Fe}-1.5 \mathrm{Si}-\mathrm{C}-\mathrm{Mn}$ system: (a) $800^{\circ} \mathrm{C}(1073 \mathrm{~K})$, (b) $740^{\circ} \mathrm{C}(1013 \mathrm{~K})$, (c) $700^{\circ} \mathrm{C}(973 \mathrm{~K})$ and (d) $600^{\circ} \mathrm{C}(873 \mathrm{~K})$. Chemical compositions of $\gamma$ phase measured by FE-EPMA for different annealing and quenching temperatures are shown as solid circles and open squares for $T_{\mathrm{a}}=800$ and $740^{\circ} \mathrm{C}(1073$ and $1013 \mathrm{~K})$, respectively. The $\alpha+\gamma$ two-phase region is divided into the PLE and NPLE regions for the ferrite transformation.
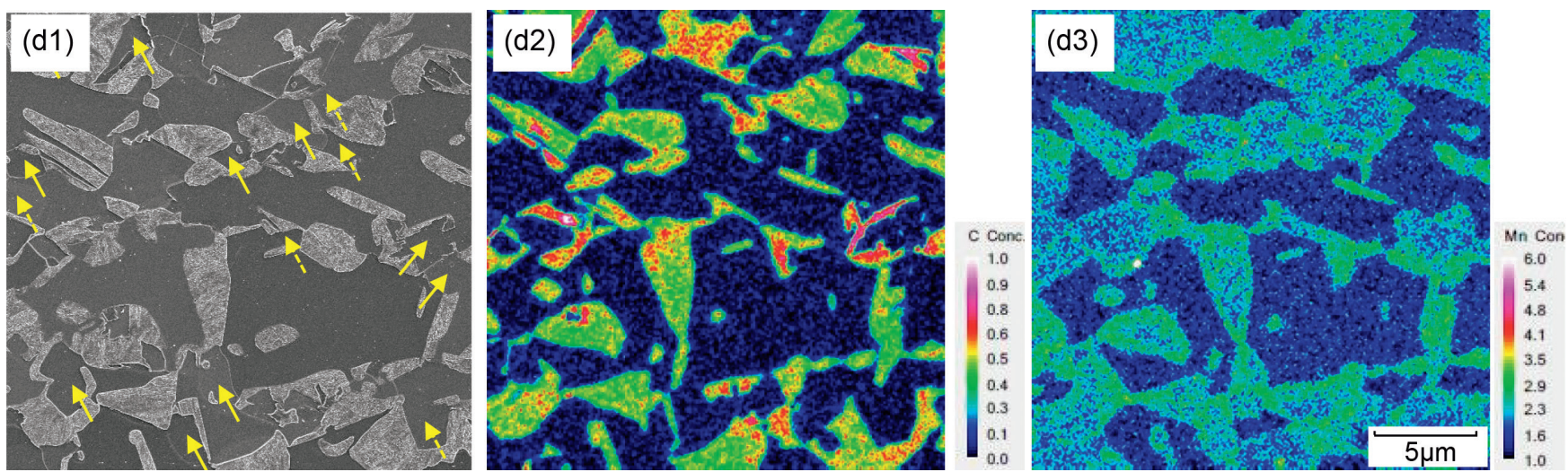

Fig. 19. SEM image and elemental mappings in Fig. $11(\mathrm{~d} 1), 11(\mathrm{~d} 2)$ and $11(\mathrm{~d} 3)$ for $T_{\mathrm{a}}=800^{\circ} \mathrm{C}(1073 \mathrm{~K}), t_{\mathrm{a}}=1.8 \mathrm{ks}$ and $T_{\mathrm{q}}=400^{\circ} \mathrm{C}(673 \mathrm{~K})$ are shown again in (a), (b) and (c), respectively. Solid and dashed arrows indicate $\alpha_{c}$ grains with and without grain boundaries, respectively, against $\alpha_{\mathrm{a}}$ grain. 
る。その Mn 濃度の低い領域がオーステナイトと焼鈍フェ ライトの界面近傍である場合, 変態フェライトは焼鈍フェ ライトからオーステナイトの Mn濃度の低い領域に向かう エピタキシャル成長により生成すると考えられる。一方, オーステナイト中の Mn 濃度の低い領域がオーステナイト と焼鈍フェライトの界面から離れた領域に存在する場合, 変態フェライトはその領域において核生成, 成長により生 成すると考えられる。後者の場合, 焼鈍フェライトと変態 フェライトの間には結晶粒界が存在することになる。以上 をまとめると, 二相域焼鈍により製造される冷延複合組織 高強度鋼板において，二相域焼鈍時に生成する焼鈍フェラ イトと, その後の冷却時に生成する変態フェライトの 2 種 類のフェライトが存在する。さらに変態フェライトは, 焼 鈍フェライトからのエピタキシャル成長により生成するも のと, オーステナイト中に扎いて核生成, 成長により生成 するものとに分けられる。

\section{5. 結言}

0.17 mass $\% \mathrm{C}-1.5$ mass\% $\% \mathrm{Si}-1.7$ mass\%Mn 鋼の二相域焼鈍 時の溶質元素の分配，およびその分配が緩冷却時のフェラ イト変態に及ぼす影響について，高精度FE-EMPAを用い た実験的な解析，およびそれをもとにした数值解析シミュ レーションを行うことにより，以下の結論を得た。

（1）焼鈍温度が $800^{\circ} \mathrm{C}$ の条件では，逆変態の初期に $\mathrm{Mn}$ およ びSiの分配を生じずにオーステナイトが急速に生成 し, その後, 焼鈍時間の増加に伴い分配が進行するの に対して, 焼鈍温度が $740^{\circ} \mathrm{C}$ の条件では, 逆変態の初期 から Mn打よび $\mathrm{Si}$ の分配を生じてオーステナイトが生 成する。焼鈍温度が $740^{\circ} \mathrm{C}$ の条件ではセメンタイトが残 存しフェライト中のC濃度が低い状態でオーステナイ トの形成が開始することから逆変態がPLEモードで進 行し, 逆変態の初期から Mn および $\mathrm{Si}$ の分配が生じる。

（2）二相域焼鈍において，C打よびSi はそれぞれオーステ ナイトとフェライトに均一に濃化するのに対して, Mn はオーステナイト中で結晶粒の中央に対して粒界付近 の濃度が高くなる不均一な分布をもってオーステナイ 卜に濃化する。オーステナイト中の Mn濃度の変化量 は, $800^{\circ} \mathrm{C}, 1.8 \mathrm{ks}$ 打よび $740^{\circ} \mathrm{C}, 14.4 \mathrm{ks}$ の焼鈍条件にお いて，それぞれ約 1.4 および 1.0 mass\%となる。

（3） $800^{\circ} \mathrm{C}, 1.8 \mathrm{ks}$ の焼鈍条件では，緩冷却時に $700^{\circ} \mathrm{C}$ から $600^{\circ} \mathrm{C}$ の温度域でフェライト変態が進行するのに対し て, $740^{\circ} \mathrm{C}, 14.4 \mathrm{ks}$ の焼鈍条件ではフェライト変態はほ とんど生じない。これらは，オーステナイト中のCお よびMn濃度によるNPLEとPLEの変態モードの差異 で説明される。
（4）二相域焼鈍により製造される冷延複合組織高強度鋼 板において，二相域焼鈍時に生成する焼鈍フェライト と, その後の冷却時に生成する変態フェライトの 2 種 類のフェライトが存在し, 焼鈍フェライトに対して変 態フェライトの方が $\mathrm{Mn}$ 濃度が高い。さらに変態フェ ライトは, 焼鈍フェライトからのエピタキシャル成長 により生成するものと,オーステナイト中において核 生成, 成長により生成するものとに分けられる。

\section{文献}

1) G.R.Speich, V.A.Demarest and R.L.Miller: Metall. Trans. A, 12(1981), 1419.

2 ) Y.Toji, T.Yamashita, K.Nakajima, K.Okuda, H.Matsuda, K.Hasegawa and K.Seto: ISIJ Int., 51(2011), 818.

3 ) P.A.Wycliffe, G.R.Purdy and J.D.Embury: Can. Metall. Q., 20(1981), 339.

4 ) K.Zhu, H.Chen, J.P.Masse, O.Bouaziz and G.Gachet: Acta Mater., 61(2013), 6025.

5 ) T.Nakagaito, H.Matsuda, Y.Nagataki and K.Seto: ISIJ Int., 57(2017), 380.

6 ) T.Yamashita, M.Enomoto, Y.Tanaka, H.Matsuda and M.Nagoshi: Tetsu-to-Hagané, 103(2017), 622 (in Japanese).

7 ) T.Yamashita, Y.Tanaka, M.Nagoshi and K.Ishida: Sci. Rep., 6(2016), Article No.29825, https://doi.org/10.1038/srep29825

8 ) T.R.Sweatman and J.V.P.Long: J. Petrol., 10(1969), 332.

9 ) X.L.Cai, A.J.Garratt-Reed and W.S.Owen: Metall. Trans. A, 16(1985), 543.

10) H.Shirasawa and J.G.Thomson: Trans. Iron Steel Inst. Jpn., 27(1987), 360.

11) L.Schemmann, S.Zaefferer, D.Raabe, F.Friedel and D.Mattissen: Acta Mater., 95(2015), 386.

12) H.Dannoshita, T.Ogawa, K.Maruoka and K.Ushioda: Mater. Trans., 60(2019), 165 .

13) S.Sun and M.Pugh: Mater. Sci. Eng., 276(2000), 167.

14) N.Pussegoda, W.R.Tyson, P.Wycliffe and G.R.Purdy: Metall.Trans. A, 15(1984), 1499.

15) J.Rudnizki, B.Bottger, U.Prahl and W.Bleck: Metall. Mater. Trans. $A, \mathbf{4 2}(2011), 2516$.

16) Z.Q.Liu, G.Miyamoto, Z.G.Yang and T.Furuhara: Metall. Mater. Trans. A, 44(2013), 4872.

17) M.Hillert: Metall. Trans. A, 6(1975), 5.

18) J.B.Gilmour, G.R.Purdy and J.S.Kirkaldy: Metall. Trans., 3(1972), 3213.

19) H.I.Aaronson and H.A.Domian: Trans. Metall. Soc. AIME, 236(1966), 781.

20) C.Atkinson, T.Akbay and R.C.Reed: Acta. Metall. Mater., 43(1995), 2013.

21) H.Guo, G.R.Purdy, M.Enomoto and H.I.Aaronson: Metall. Mater. Trans. A, 37(2006), 1721.

22) X.Zhang, G.Miyamoto, T.Kaneshita, Y.Yoshida, Y.Toji and T.Furuhara: Acta Mater., 154(2018), 1.

23) G.S.Huppi, D.K.Matlock and G.Krauss: Scr. Metall., 14(1980), 1239.

24) M.Erdogan and R.Priestner: Mater. Sci. Technol., 15(1999), 1273.

25) M.Erdogan and R.Priestner: Mater. Sci. Technol., 18(2002), 369. 